Florida State University College of Law

Scholarship Repository

Scholarly Publications

$11-2014$

\title{
A House Divided: When State and Lower Federal Courts Disagree on Federal Constitutional Rights
}

Wayne A. Logan

Florida State University College of Law

Follow this and additional works at: https://ir.law.fsu.edu/articles

Part of the Constitutional Law Commons

\section{Recommended Citation}

Wayne A. Logan, A House Divided: When State and Lower Federal Courts Disagree on Federal Constitutional Rights, 90 NOTRE DAME L. REV. 235 (2014),

Available at: https://ir.law.fsu.edu/articles/161

This Article is brought to you for free and open access by Scholarship Repository. It has been accepted for inclusion in Scholarly Publications by an authorized administrator of Scholarship Repository. For more information, please contact efarrell@law.fsu.edu. 


\title{
A HOUSE DIVIDED: WHEN STATE AND LOWER
}

\section{FEDERAL COURTS DISAGREE ON FEDERAL CONSTITUTIONAL RIGHTS}

\author{
Wayne A. Logan* \\ "The operation of a double system of conflicting laws in the same state is plainly \\ hostile to the reign of law. Janus was not a god of justice."
}

Despite our many differences, "We the People"2 take as a given that rights contained in our Federal Constitution will apply with equal force throughout the land. As John Jay put it in The Federalist No. 22, "we have uniformly been one people; each individual citizen everywhere enjoying the same national rights, privileges, and protection." ${ }^{3}$ To better ensure federal rights uniformity, the Framers included the Supremacy Clause in the Constitution $^{4}$ and ordained that there be "one supreme Court" 5 to harmonize what Justice Joseph Story termed "jarring and discordant judgments" 6 of lower courts, giving rise to "public mischiefs."7

(C) 2014 Wayne A. Logan. Individuals and nonprofit institutions may reproduce and distribute copies of this Article in any format at or below cost, for educational purposes, so long as each copy identifies the author, provides a citation to the Notre Dame Law Review, and includes this provision in the copyright notice.

* Gary \& Sallyn Pajcic Professor of Law, Florida State University College of Law. Thanks to Professors Robert Ahdieh, Joe Blocher, Aaron Bruhl, Barry Friedman, Mike Gerhardt, Abbe Gluck, Kyle Graham, Ron Krotoszynski, Kay Levine, Jonathan Nash, Richard Re, Chris Slobogin, Michael Solimine, Sam Wiseman, Ron Wright, and workshop participants at the Florida State University College of Law and Emory University School of Law for their very helpful comments. Thanks also to AnnaLaura Rehwinkel, Keith Savino, and Amber Stoner for their wonderful research assistance.

1 Felix Frankfurter, Distribution of Judicial Power Between United States and State Courts, 13 Cornell L.Q. 499, 525 (1928).

2 U.S. CONST. pmbl.

3 The Federalist No. 2, at 38-39 (John Jay) (Clinton Rossiter ed., 1961).

4 U.S. Const. art. VI, cl. 2 (stating that " $[\mathrm{t}]$ his Constitution . . . shall be the supreme Law of the Land").

$5 \quad I d$. art. III, $\S 1$. Circuit riding by the Justices provides further evidence of the desire for uniformity, vis-à-vis the lower federal courts. See Barry Friedman, Under the Law of Federal Jurisdiction: Allocating Cases Between Federal and State Courts, 104 Colum. L. Rev. 1211, 1218 (2004).

6 Martin v. Hunter's Lessee, 14 U.S. (1 Wheat.) 304, 348 (1816) (Story, J.).

7 Id.; see also Cohens v. Virginia, 19 U.S. (6 Wheat.) 264, 416 (1821) (Marshall, C.J.) (positing the "necessity of uniformity" on federal constitutional matters); Martin, 14 U.S. 
Federal constitutional rights, however, have never applied in uniform fashion nationwide, and rights uniformity has long numbered among the legal myths de Tocqueville recognized as central to American governance. ${ }^{8}$ In a recent article, I chronicled how federal rights disuniformity plays out in the context of the nation's twelve regional federal circuit courts of appeal. ${ }^{9}$ Focusing on Fourth Amendment doctrine in particular, the article highlighted the existence of over three dozen circuit splits, many concerning quite common and basic search and seizure issues. ${ }^{10}$

The variation underscored the challenge entailed in realizing the Supreme Court's expectation that the Fourth Amendment is "enforceable in the same manner and to like effect" nationwide. ${ }^{11}$ The article also surveyed the many practical and theoretical ramifications of what Justice Scalia recently condemned as a "crazy quilt" of federal constitutional rights, ${ }^{12}$ generated by a single sovereign's judicial system-the nation's federal circuit courts.

This Article shifts focus, examining state court contributions to federal constitutional diversity. Typically operating out of the public and scholarly limelight, state courts have long shared a concurrent obligation with lower federal courts to interpret the U.S. Constitution ${ }^{13}$ and protect the rights contained in it. ${ }^{14}$ Critically important as well, state courts do so independently of their federal counterparts. They need not defer to the constitutional posi-

(1 Wheat.) at 347-48 (Story, J.) (stressing need for uniformity "throughout the whole United States, upon all subjects within the purview of the constitution" and condemning disuniformity as "truly deplorable").

8 Alexis de Tocqueville, Democracy in America 150 (J.P. Mayer \& Max Lerner eds., George Lawrence trans., Harper \& Row 1966) (1835) (observing that "[t]he government of the Union rests almost entirely on legal fictions").

9 See Wayne A. Logan, Constitutional Cacophony: Federal Circuit Splits and the Fourth Amendment, 65 VAND. L. Rev. 1137 (2012).

10 Id. at $1148-50$.

11 Mapp v. Ohio, 367 U.S. 643, 660 (1961).

12 Kansas v. Marsh, 548 U.S. 163, 185 (2006) (Scalia, J., concurring); see also Danforth v. Minnesota, 552 U.S. 264, 302 (2008) (Roberts, C.J., dissenting) (asserting that federal rights must be "applied equally" in "every one of the several States" (quoting Sandra Day O'Connor, Our Judicial Federalism, 35 CASE W. Res. L. Rev. 1, 4 (1984) (internal quotation marks omitted))).

13 See Howlett v. Rose, 496 U.S. 356, 367 (1990) ("Federal [constitutional] law is enforceable in state courts . . . because the Constitution and laws passed pursuant to it are as much laws in the States as laws passed by the state legislature. The Supremacy Clause makes those laws 'the supreme Law of the Land,' and charges state courts with a coordinate responsibility to enforce that law according to their regular modes of procedure.").

14 See Arizona v. Evans, 514 U.S. 1, 8 (1995) ("State courts . . are not merely free tothey are bound to-interpret the United States Constitution."); Trainor v. Hernandez, 431 U.S. 434, 443 (1977) ("[S] tate courts have the solemn responsibility equally with the federal courts to safeguard constitutional rights . ..." (internal quotation marks omitted)); Robb v. Connolly, 111 U.S. 624, 637 (1884) ("Upon the State courts, equally with the courts of the Union, rests the obligation to guard, enforce, and protect every right granted or secured by the Constitution of the United States . . . ."). 
tions adopted by federal circuit courts, ${ }^{15}$ including those in which they are geographically situated, ${ }^{16}$ which lack direct appellate review authority over them. ${ }^{17}$ As a consequence, on all issues other than the comparatively narrow range of questions expressly addressed by the Supreme Court, ${ }^{18}$ state and lower federal courts are free to disagree, creating conditions ripe for the constitutional conflict feared by the Framers.

This Article provides the first in-depth examination of state-federal concurrent constitutional authority and does so by focusing on a context in which its consequences are most problematic: within individual states. While a handful of articles over the years have examined state court power vis-à-vis federal constitutional questions more generally, ${ }^{19}$ no systematic effort has been undertaken to examine intrastate, state-federal conflict on federal con-

15 See State v. Coleman, 214 A.2d 393, 403 (N.J. 1965) ("In passing on federal constitutional questions, the state courts and the lower federal courts have the same responsibility and occupy the same position; there is parallelism but not paramountcy for both sets of courts are governed by the same reviewing authority of the Supreme Court.").

16 See, e.g., Owsley v. Peyton, 352 F.2d 804, 805 (4th Cir. 1965) ("Though state courts may for policy reasons follow the decisions of the Court of Appeals whose circuit includes their state they are not obliged to do so." (citation omitted)); State v. McDowell, 310 S.E.2d 301, 310 (N.C. 1984) (noting that it "accord[s] . . decisions of lower federal courts such persuasiveness as these decisions might reasonably command").

17 See United States ex rel. Lawrence v. Woods, 432 F.2d 1072, 1076 (7th Cir. 1970) (noting that "because lower federal courts exercise no appellate jurisdiction over state tribunals, decisions of lower federal courts are not conclusive on state courts").

18 See Elmendorf v. Taylor, 23 U.S. (10 Wheat.) 152, 160 (1825) (“[T]he construction given by this Court to the constitution and laws of the United States is received by all as the true construction ...."). Yet even on matters that the Court has addressed uncertainty can remain, given the commonly indeterminate nature of precedent. See Evan H. Caminker, Precedent and Prediction: The Forward-Looking Aspects of Inferior Court Decisionmaking, 73 Tex. L. REv. 1, 10-11 (1994) ("Deciding what a precedent means will frequently depend on the particular normative values and assumptions each judge brings to the interpretive enterprise."). At the same time, from the perspective of lower courts, the Court's decisions often can leave open as many questions as they resolve. See Carey v. Musladin, 549 U.S. 70, 76 (2006) (acknowledging that lower court conflicts "[r] eflect[ ] [a] lack of guidance from this Court"); Adam Liptak, Justices Long on Words but Short on Guidance, N.Y. Times, Nov. 18, 2010, at A1. Not to be overlooked as well is the modern Court's penchant for plurality opinions, which can make it difficult to discern operable rules. See generally Justin Marceau, Plurality Decisions: Upward-Flowing Precedent and Acoustic Separation, 45 Conn. L. Rev. 933, 936 (2013).

19 Of these, Professor Paul Bator's brief article written over three decades ago is the most significant. See Paul M. Bator, The State Courts and Federal Constitutional Litigation, 22 WM. \& MARY L. Rev. 605 (1981). Even when examined, however, state court power to differ on federal constitutional questions has been misunderstood. See, e.g., Jason Mazzone, The Bill of Rights in the Early State Courts, 92 Minn. L. Rev. 1, 73-74 (2007) ("Today, a single body of federal constitutional law, generated by the United States Supreme Court through [its] power to review all state court decisions on federal constitutional issues, means that citizens do not live with different federal constitutional rights depending on the decisions of their state courts."). 
stitutional questions. ${ }^{20}$ This Article redresses this deficit, using as its doctrinal locus federal constitutional criminal procedure, with its unique impact on government power and individual liberty and privacy.

The Article proceeds as follows: Part I begins by providing an overview of the growing power of state courts to interpret and apply federal constitutional provisions, and then considers the important benefits of state court involvement. State court decisions, much like state legislative enactments extolled by Justice Brandeis, ${ }^{21}$ provide a basis for real-world experiments to gauge the effects of doctrine, cabined (unlike the decisions of federal circuits) to individual states. The decisions themselves, moreover, originate in a context that is in many ways distinct from that of federal courts. State courts process a massively greater number of criminal cases, affording them corresponding greater experience with criminal procedure matters; they also function in a decidedly different institutional environment, including having to stand for election. Over the years this latter distinction has fueled the expectation that state courts will reflexively endorse pro-government positions on civil liberty questions, ${ }^{22}$ an expectation belied by the results of a survey reported on here of state court decisions coming before the Roberts Court.

Part II examines how state courts go about operationalizing their federal constitutional interpretive power alongside the federal circuits. Despite some lingering scholarly doubt on the question, ${ }^{23}$ and resistance from the Ninth Circuit in particular, ${ }^{24}$ today the vast majority of state courts address

20 The work that has been done has failed to focus on constitutional conflict and gives short shrift to its many important practical and theoretical ramifications. See Colin E. Wrabley, Applying Federal Court of Appeals' Precedent: Contrasting Approaches to Applying Court of Appeals' Federal Law Holdings and Erie State Law Predictions, 3 Seton Hall Cir. Rev. 1, 16-28 (2006); Donald H. Zeigler, Gazing into the Crystal Ball: Reflections on the Standards State Judges Should Use to Ascertain Federal Law, 40 Wм. \& Mary L. Rev. 1143 (1999); Andrew A. Matthews, Jr., Comment, The State Courts and the Federal Common Law, 27 Alb. L. Rev. 73 (1963); Note, Authority in State Courts of Lower Federal Court Decisions on National Law, 48 Colum. L. REv. 943 (1948) [hereinafter Authority in State Courts].

21 See New State Ice Co. v. Liebmann, 285 U.S. 262, 310-11 (1932) (Brandeis, J., dissenting) (extolling value of social and economic legislative "experiments" undertaken "without risk to the rest of the country").

22 See Anthony G. Amsterdam, Criminal Prosecutions Affecting Federally Guaranteed Civil Rights: Federal Removal and Habeas Corpus Jurisdiction to Abort State Court Trial, 113 U. PA. L. Rev. 793, 802 (1965); Burt Neuborne, The Myth of Parity, 90 Harv. L. Rev. 1105, 1116 nn.45-46 (1977).

23 See Charles Alan Wright \& Mary Kay Kane, Law of Federal Courts $§ 45$ n.25 (6th ed. 2002) (noting the "interesting question of the weight state courts should give to decisions of lower federal courts when the state court is applying federal law"); Kevin M. Clermont, Reverse-Erie, 82 Notre Dame L. Rev. 1, 31 (2006) (“[T] he question of whether state courts are bound by lower federal courts on the federal law's content remains open.”); Steven G. Gey, The Myth of State Sovereignty, 63 Оніо Sт. L.J. 1601, 1663-64 (2002) ("The hubris of state courts that refuse to follow the definitive interpretations of federal law made by the federal courts with jurisdiction over the state's territory is remarkable ....”).

24 See Hopkins v. Bonvicino, 573 F.3d 752, 769 (9th Cir. 2009) ("It is the federal courts that are the final arbiters of federal constitutional rights, not the state courts."); Bennett v. 
federal constitutional questions free of any felt need to defer to federal circuits, including their own. ${ }^{25}$

The power-sharing arrangement gives rise to doctrinal conflicts on multiple important constitutional criminal procedure questions. For instance, the California Supreme Court and the Ninth Circuit disagree on whether the "community caretaking" doctrine can justify the warrantless entry of a home by police, ${ }^{26}$ as do the Wisconsin Supreme Court and the Seventh Circuit. ${ }^{27}$ State and federal circuits differ on any number of other search and seizure questions, including whether police can perform a protective "frisk" for weapons in the absence of reasonable suspicion that the individual targeted is engaged in criminal wrongdoing. ${ }^{28}$ Similar conflicts exist in the Fifth and Sixth Amendment contexts with respect to confessions. ${ }^{29}$

The conflicts create an array of significant difficulties. Perhaps most notably, basic rule of law expectations are undercut when national constitutional law is permitted to depend on the uniform worn by law enforcement agents or the court in which a criminal case is filed. While state constitutional norms can and do vary, here the divergent doctrinal positions emanate from the same legal source, the U.S. Constitution, which controls regardless of the government actor or court ${ }^{30}$ and which citizens accept as the national

Mueller, 322 F.3d 573, 582 (9th Cir. 2003) ("[S] tate courts will not be the final arbiters of important issues under the federal constitution . . .." (quoting Minnesota v. Nat'l Tea Co., 309 U.S. 551, 557 (1940))). Notably, the circuit has persisted in its position despite a prior chastening by the Supreme Court. See Arizonans for Official English v. Arizona, 520 U.S. 43, 58 n.11 (1997) (terming the Ninth Circuit's suggestion of state court subservience "remarkable").

25 See, e.g., Johnson v. Williams, 133 S. Ct. 1088, 1098 (2013) (noting that "the views of the federal courts of appeals do not bind the California Supreme Court when it decides a federal constitutional question”); Lockhart v. Fretwell, 506 U.S. 364, 376 (1993) (Thomas, J., concurring) ("The Supremacy Clause demands that state law yield to federal law, but neither federal supremacy nor any other principle of federal law requires that a state court's interpretation of federal law give way to a (lower) federal court's interpretation.").

26 Compare United States v. Erickson, 991 F.2d 529, 531 (9th Cir. 1993) (disallowing warrantless entry of home based on the community caretaking rationale), with People v. Ray, 981 P.2d 928, 938 (Cal. 1999) (allowing warrantless entry), cert. denied, 528 U.S. 1187 (2000).

27 Compare United States v. Pichany, 687 F.2d 204, 208-09 (7th Cir. 1982) (disallowing warrantless entry), with State v. Pinkard, 785 N.W.2d 592, 601 (Wis. 2010) (allowing warrantless entry), cert. denied, 131 S. Ct. 1001 (2011).

28 Compare United States v. Orman, 486 F.3d 1170, 1173 (9th Cir. 2007) (allowing frisk in the absence of lawful seizure), with State v. Serna, 431 P.3d 406, 410 (Ariz. 2014) (expressly rejecting the Ninth Circuit position); compare United States v. Burton, 228 F.3d 524, 528 (4th Cir. 2000) (stating that in a consensual encounter "an officer may not conduct [a] protective search for purposes of safety until he has a reasonable suspicion [of criminal activity]"), with Bailey v. State, 987 A.2d 72, 83 (Md. 2010) (explaining that an "articulable suspicion to believe that criminal activity [is] afoot" is not necessary in order to conduct a protective pat-down search during a consensual encounter).

29 See infra notes 152-56 and accompanying text.

30 See O'Connor, supra note 12, at 4 (positing that "a single sovereign's laws should be applied equally to all”). 
civic norm. ${ }^{31}$ When this occurs, individual rights and the scope of government power are left to happenstance, calling into question basic expectations of governmental consistency and even-handedness. The variable rights regime, in turn, creates the risk of forum shopping as prosecutors strategically gravitate toward more prosecution-friendly doctrines.

Conflicts also affect civil rights litigation. For instance, when a state court and its coordinate federal circuit court disagree on whether a particular law enforcement actor (e.g., a county sheriff) qualifies as a state agent, triggering Eleventh Amendment immunity, the forum-filing decisions of plaintiffs (not prosecutors) are affected. By the same token, when a court adopts a more rights-restrictive position, law enforcement will enjoy qualified immunity, resulting in a right recognized by the other court going unenforced.

Ultimately, the conflicts themselves, in the wake of very significant limits placed on the scope of federal habeas corpus review, ${ }^{32}$ can only be mediated by the nation's "one supreme Court." 33 While lower courts beseech the Supreme Court to resolve issues, ${ }^{34}$ multiple intrastate conflicts exist as the Court contents itself with resolving only eighty or so cases a Term, ${ }^{35}$ a vastly diminished docket by historical standards. ${ }^{36}$ This is so despite the fact that the Justices continue to insist upon the importance of uniformity, ${ }^{37}$ and the reality that the Court's own rules provide that state-federal conflict qualifies

31 See James A. Gardner, Interpreting State Constitutions 23 (2005) (noting that "[w] hen Americans speak of 'constitutional law,' they invariably mean the U.S. Constitution"); Akhil Reed Amar, Did the Fourteenth Amendment Incorporate the Bill of Rights Against States?, 19 Harv. J.L. \& Pub. Pol'y 443, 444 (1996) (observing that when Americans speak of "rights" they refer to those embodied in the Federal Bill of Rights).

32 See infra notes 242-45 and accompanying text.

33 U.S. Const. art. III, § 1.

34 See, e.g., Venegas v. Cnty. of L.A., 87 P.3d 1, 21 (Cal. 2004) (noting a dispute with Ninth Circuit on whether a sheriff is a state actor under 42 U.S.C. $\$ 1983$ and urging the Supreme Court to "decide which view is correct" because the split "effectively drives . . . actions against a county sheriff out of our court system and into federal court"); Feis v. King Cnty. Sheriff's Dep't, 267 P.3d 1022, 1033 n.13 (Wash. Ct. App. 2011) (noting the prior denial of a certiorari petition to resolve an ongoing split on whether the community caretaking exception extends to home entries by police), review denied, 277 P.3d 669 (Wash. 2012).

35 The Supreme Court-The Statistics, 127 Harv. L. Rev. 408, 416 (2013) (noting that the Court granted certiorari in 83 cases on its appellate docket, and granted $1.2 \%$ of petitions filed overall).

36 See Ryan J. Owens \& David A. Simon, Explaining the Supreme Court's Shrinking Docket, 53 Wm. \& Mary L. Rev. 1219, 1251 (2012) (stating that "the Court hears fewer cases these days than any other time in [its] modern history" and providing data in support); Kenneth W. Starr, The Supreme Court and Its Shrinking Docket: The Ghost of William Howard Taft, 90 Minn. L. Rev. 1363, 1366 (2006) (noting that we are witnessing " $[t]$ he great disappearing merits docket").

37 See, e.g., Justices in Their Own Words: Granting Certiorari (C-SPAN television broadcast June 19, 2009), http://supremecourt.c-span.org/Video/JusticeOwnWords.aspx (last visited Oct. 30, 2014) (Chief Justice John Roberts) ("Our main job is to try to make sure [that] federal law is uniform across the country."). 
as a "compelling reason[ ]" to grant certiorari. ${ }^{38}$ Meanwhile, in the handful of cases that it agrees to hear, the Court blithely elides the reality of intrastate conflicts, electing instead to note only the existence of federal circuit splits or discord on a question more generally. ${ }^{39}$

Part III canvasses the reform proposals advanced to date designed to mediate state-federal constitutional conflict. Finding each wanting, Part IV offers an alternative, one hiding in plain view: amendment of the federal certification provision. ${ }^{40}$ Although federal courts have enjoyed authority since 1802 to certify disputed questions to the Supreme Court for resolution, Congress has never extended such authority to state courts. Expanding certification to include state and federal courts alike would have several important benefits. In addition to ensuring the speedy resolution of intrastate constitutional conflicts, and curing the serious problems that they create, the expansion will elevate state courts to their rightful place in federal constitutional discourse. It will also help pave the way for a more engaged relationship between state and lower federal courts and the Supreme Court charged with overseeing their work and ensuring federal constitutional consistency.

\section{State Court Authority and Its Benefits}

\section{A. Historical Evolution}

State courts have long played a role in federal constitutional litigation. Their authority to decide federal constitutional questions, however, arises chiefly on an inferential basis: Article III speaks only of "one supreme Court," and fails to require creation of lower federal courts, ${ }^{41}$ leaving state courts by default as decisionmakers. ${ }^{42}$ Lower federal courts, created by Congress

38 See Sup. CT. R. 10(a)-(c).

39 See, e.g., Fernandez v. California, 134 S. Ct. 1126, 1131 \& n.4 (2014) (noting only that the California court agreed with a "majority of the federal circuits" while ignoring that the court's position conflicted with the position adopted by the Ninth Circuit); Arizona v. Gant, 556 U.S. 332, 338 (2009) (citing a "chorus . . . includ[ing] courts, scholars, and Members of this Court" calling for its prior decision in New York v. Belton to be revisited, yet ignoring that the Arizona Supreme Court's decision limiting Belton created a conflict with the Ninth Circuit); Georgia v. Randolph, 547 U.S. 103, 108 (2006) (referring only to a "split of authority" on whether police can enter a home when a physically present co-occupant objects, failing to note the conflict in question between the Georgia Supreme Court and the Eleventh Circuit).

$40 \quad$ See 28 U.S.C. $\$ 1254$ (2012).

41 U.S. Const. art. III, $\S 1$ (vesting judicial power in "one supreme Court, and in such inferior Courts as the Congress may from time to time ordain and establish").

42 See 1 Julius Goebel, Jr., History of the Supreme Court of the United States: Antecedents ANd Beginnings to 1801, at 211 (1971) (noting that lower federal courts were not needed because state courts were regarded as "adequate"); see also Matthew I. Hall, Asymmetrical Jurisdiction, 58 UCLA L. Rev. 1257, 1263 (2011); James E. Pfander, Federal Supremacy, State Court Inferiority, and the Constitutionality of Jurisdiction-Stripping Legislation, 101 Nw. U. L. Rev. 191, 216-17 (2007). 
shortly after the nation's founding, ${ }^{43}$ did not come to enjoy general federal question jurisdiction until $1875 .^{44}$

Even though the Judiciary Act of 1789 signaled a degree of mistrust of state courts, ${ }^{45}$ and despite concerns expressed over their skill and trustworthiness, ${ }^{46}$ state courts figured centrally in the nation's early constitutional life. ${ }^{47}$ While Barron $v$. Baltimore made clear that state and local governments were not subject to the Federal Bill of Rights, ${ }^{48}$ antebellum state courts regularly engaged in federal constitutional common lawmaking on their own initiative. ${ }^{49}$ As Professor Jason Mazzone has observed, "[i] n a series of cases that are largely forgotten or brushed aside today, early state courts regularly did

43 See Judiciary Act of 1789 , ch. 20, $\S \S 3-4,1$ Stat. 73, 73-75. On what has come to be known as the Madisonian Compromise, leaving to Congress authority to create lower federal courts, see Richard H. Fallon, Jr. et al., Hart and Wechsler's The Federal Courts and the Federal System 7-9 (5th ed. 2003).

44 See Zwickler v. Koota, 389 U.S. 241, 246-47 \& n.8 (1967) (noting the same, based on Act of Mar. 3, 1875, ch. 137, § 1, 18 Stat. 470, 470); see also Gautham Rao, The Federal Posse Comitatus Doctrine: Slavery, Compulsion, and Statecraft in Mid-Nineteenth-Century America, 26 LAw \& Hist. Rev. 1, 17 (2008) ("In the general constitutional order of the early republic, the lower federal courts played but a peripheral role in an era dominated by the ascendancy of the common law and state judiciaries.").

45 The Act empowered the Supreme Court to review by writ of error any decision in which a state court denied a federal right, title, or interest, which as Professor James Pfander has noted "doubtless reflected some distrust of the state courts." Pfander, supra note 42, at 232. Based on authority granted in Article III, section 2, the Act similarly granted the federal judiciary diversity jurisdiction in civil cases, affording federal courts power to adjudicate claims brought by citizens of different states or non-U.S. citizens. See Henry J. Friendly, The Historic Basis of Diversity Jurisdiction, 41 HaRv. L. Rev. 483, 509 (1928).

46 Alexander Hamilton, for instance, expressed concern that state courts would fail to consider national interests because of "local views and prejudices" and "look with peculiar deference towards that authority to which they owe their official existence." The FederalIST No. 22, at 113 (Alexander Hamilton) (Ian Shapiro ed., 2009). As Brian Fitzpatrick has noted, however, Hamilton was also prone to lavishing state courts with praise for their independence and competence. See Brian T. Fitzpatrick, The Constitutionality of Federal Jurisdiction-Stripping Legislation and the History of State Judicial Selection and Tenure, 98 VA. L. REv. 839, 874-75 (2012). Likewise, Judge Friendly's survey of Framing-era state cases suggests that diversity jurisdiction was motivated not so much by fear of state judicial prejudice but rather worry over state legislatures. Friendly, supra note 45, at 495-97; see also Martin v. Hunter's Lessee, 14 U.S. (1 Wheat.) 304, 346 (1816) (Story, J.) (“[T] he judges of the state courts are, and always will be, of as much learning, integrity, and wisdom, as those of the courts of the United States .....").

47 See Pfander, supra note 42, at 209, 218-19.

4832 U.S. (7 Pet.) 243, 247, 250-51 (1833) (dismissing for want of jurisdiction a Fifth Amendment Takings Clause claim against the City of Baltimore).

49 See Jason Mazzone, When the Supreme Court Is Not Supreme, 104 Nw. U. L. Rev. 979, 990 (2010) (" $[\mathrm{S}]$ tate courts understood the Bill either to apply directly to state governments or to set out general constitutional principles that bound the states, even when their own constitutions imposed no such constraint."); see also Mazzone, supra note 19, at 3 ("Barron simply affirmed the unremarkable proposition that the federal courts would not apply the Bill of Rights to constrain state government. Both before and after Barron ... state courts were free to apply the Bill of Rights to the states."). 
apply the Federal Bill of Rights to invalidate state laws and otherwise constrain state government." 50 State courts, Professor Mazzone notes, served as "an important mechanism for protecting individual rights in the antebellum era." 51

State courts, moreover, long enjoyed a considerable degree of decisional autonomy. For much of the nation's history, the Supreme Court exercised jurisdiction only over state cases that rejected federal constitutional claims. ${ }^{52}$ It was not until 1914 that Congress, concerned over what Professors Frankfurter and Landis termed "a wide-spread feeling that, in practice, constitutionality turned on geography," 53 extended to the Court full jurisdiction over state courts, authorizing review of their decisions that allowed (not merely rejected) federal constitutional claims and defenses. ${ }^{54}$

In addition, due to the slow emergence of habeas corpus authority, state courts operated free of lower federal court oversight. The latter did not come to have habeas review authority over state criminal cases until after the Civil War, and then only with respect to the jurisdiction of the sentencing court. ${ }^{55}$ Not until 1953 were lower federal courts empowered to review the validity of state court convictions implicating federal constitutional claims. ${ }^{56}$

Over time, state courts have come to play an ever-greater role in federal constitutional litigation. ${ }^{57}$ Starting in the mid-twentieth century, the Supreme Court, through gradual application of the incorporation doc-

50 Mazzone, supra note 19, at 3; see also Mazzone, supra note 49, at 985-90 (surveying state cases).

51 Mazzone, supra note 19, at 23. For discussion of early state cases focusing on the Fourth Amendment and police search and seizure practices in particular, see BRADFORD P. Wilson, Enforcing the Fourth Amendment 31-33, 116-17 (1986).

52 Judiciary Act of 1789 , ch. $20, \S 25,1$ Stat. 85, 85-87. Further testament to state authority, in 1830 Congress considered (but did not approve) eliminating Supreme Court review of state court decisions. See Leonard G. Ratner, Congressional Power over the Appellate Jurisdiction of the Supreme Court, 109 U. PA. L. Rev. 157, 159 (1960). According to the bill's sponsor, Senator William Jenner:

There is no need for any national uniformity with respect to these matters. They are things for each State to decide for itself. Leaving the decisions in each State to the highest court of the State, and taking from the Supreme Court . . . any power to step in and impose an arbitrary rule, can only be a salutary thing . . . . Id. at $159 \mathrm{n} .11$ (citation omitted) (internal quotation marks omitted).

53 Felix Frankfurter \& James M. Landis, The Business of the Supreme Court 195 (1928).

54 Act of Dec. 23, 1914, ch. 2, 38 Stat. 790.

55 See Michael E. Solimine \& James L. Walker, Respecting State Courts 120 (1999).

56 Id. (noting and discussing Brown v. Allen, 344 U.S. 443 (1953)).

57 The major role played by state courts has not been without controversy, however. It has been asserted, for instance, that state court involvement only made sense before 1875 , when the number and role of lower federal courts significantly expanded. See Samuel P. Jordan, Reverse Abstention, 92 B.U. L. REv. 1771, 1789 (2012) (asserting that "the Madisonian Compromise grew out of uncertainty that has been resolved definitively for more than a century"). Lack of confidence in the even-handedness of states more generally of course also figured centrally in the adoption of the Fourteenth Amendment. See generally Michael Kent Curtis, No State Shall Abridge (1986) (arguing that the Fourteenth 
trine, ${ }^{58}$ formally subjected states to the criminal procedure provisions of the Bill of Rights. ${ }^{59}$ Acting on this authority, state courts have since left an indelible mark, ${ }^{60}$ as the multiple state cases resulting in landmark criminal procedure precedents from the Warren Court ${ }^{61}$ through the Roberts Court ${ }^{62}$ attest.

As discussed next, moreover, state court participation in the evolution of federal constitutional criminal procedure doctrine has a variety of important functional benefits.

\section{B. The Functional Benefits of State Court Power}

\section{Experimentation}

Invoking Justice Brandeis's ideal, ${ }^{63}$ it has long been asserted that the independent decisionmaking authority of the nation's regionally arrayed twelve federal circuit courts afford experimentalist benefit. ${ }^{64}$ If one accepts

Amendment was intended to prevent states from violating rights contained in the Bill of Rights).

58 See generally Jerold H. Israel, Selective Incorporation: Revisited, 71 GEO. L.J. 253 (1982).

59 The influx of criminal procedure cases was dramatically evidenced in state court dockets. See Robert A. Kagan et al., The Business of State Supreme Courts, 1870-1970, 30 Stan. L. REv. 121, 145-47 (1977) (discussing data showing massive increases in federal constitutional criminal procedure matters during the study period); Daniel J. Meltzer, State Court Forfeitures of Federal Rights, 99 Harv. L. Rev. 1128, 1131 n.7 (1986) (noting that by 1970 almost fifty percent of state supreme court criminal cases presented a federal constitutional law question).

60 See Danforth v. Minnesota, 552 U.S. 264, 272 (2008) ("The serial incorporation of the Amendments in the Bill of Rights during the 1950's and 1960's imposed more constitutional obligations on the States and created more opportunity for claims that individuals were being convicted without due process and held in violation of the Constitution.").

61 See, e.g., Chimel v. California, 395 U.S. 752 (1969); Schmerber v. California, 384 U.S. 757 (1966); Miranda v. Arizona, 384 U.S. 436 (1966); Spano v. New York, 360 U.S. 315 (1959).

62 See, e.g., Montejo v. Louisiana, 556 U.S. 778 (2009); Illinois v. Wardlow, 528 U.S. 119 (2000); Wyoming v. Houghton, 526 U.S. 295 (1999); Minnesota v. Dickerson, 508 U.S. 366 (1993); California v. Acevedo, 500 U.S. 565 (1991); Horton v. California, 496 U.S. 128 (1990); Maryland v. Buie, 494 U.S. 325 (1990); Colorado v. Bertine, 479 U.S. 367 (1987); New York v. Quarles, 467 U.S. 649 (1984); Illinois v. Gates, 462 U.S. 213 (1983); New York v. Belton, 453 U.S. 454 (1981); Delaware v. Prouse, 440 U.S. 648 (1979). While such constitutionally formative cases have usually come from state supreme courts, state intermediate courts have also been an important originating source over the years. See, e.g., Illinois v. McArthur, 531 U.S. 326 (2001); Terry v. Ohio, 392 U.S. 1 (1968).

63 See New State Ice Co. v. Liebmann, 285 U.S. 262, 311 (1932) (Brandeis, J., dissenting) ("It is one of the happy incidents of the federal system that a single courageous State may, if its citizens choose, serve as a laboratory; and try novel social and economic experiments without risk to the rest of the country.").

64 See, e.g., J. Woodford Howard, Jr., Courts of Appeals in the Federal Judicial System 81 (1981) ("[T] he quest for uniformity contains room for regional experimentation and adaptation of national law to continental diversity."). 
that constitutional rights are ripe for experimentation, ${ }^{65}$ a case can be made for the experimental role of state courts as well. ${ }^{66}$ Their decisions, like those of federal courts, are publicly available and critiqued, ${ }^{67}$ and their real-world effects can be measured and assessed. Indeed, it can be said that state court decisions better fulfill the Brandeisian ideal. This is because unlike circuit decisions, which impact several states, ${ }^{68}$ the effects of state decisions are cabined to a single state, as Justice Brandeis would have it, ${ }^{69}$ optimizing conditions for natural constitutional experiments. ${ }^{70}$

65 But see Duncan v. Louisiana, 391 U.S. 145, 170 (1968) (Black, J., concurring) ("I have never believed that under the guise of federalism the States should be able to experiment with the protections afforded our citizens through the Bill of Rights."); Griswold v. Connecticut, 381 U.S. 479, 496 (1965) (Goldberg, J., concurring) (“[W]hile I quite agree with Mr. Justice Brandeis . . . I do not believe that this includes the power to experiment with the fundamental liberties of citizens . . . . I cannot agree that the Constitution grants such power either to the States or to the Federal Government." (citation omitted) (internal quotation marks omitted)); Truax v. Corrigan, 257 U.S. 312, 338 (1921) ("The Constitution was intended, its very purpose was, to prevent experimentation with the fundamental rights of the individual.").

66 As the Ohio Supreme Court observed,

[W] e are reluctant to abandon our role in the system of federalism created by the United States Constitution until the United States Supreme Court directs us otherwise. Both inferior federal courts and state courts serve as "laboratories for experimentation to devise various solutions where the best solution is far from clear."

State v. Burnett, 755 N.E.2d 857, 862 (Ohio 2001) (quoting United States v. Lopez, 514 U.S. 549, 581 (1995) (Kennedy, J., concurring)); see also William W. Schwarzer et al., Judicial Federalism in Action: Coordination of Litigation in State and Federal Courts, 78 VA. L. Rev. 1689,1746 (1992) (extolling the "value of fifty laboratories in which approaches to federal law can be tested").

67 While Justice Brandeis had state legislatures in mind, Professors Marc Miller and Ronald Wright have persuasively argued that the laboratory trope is especially apt in the context of state caselaw:

Active state interpretations and responses to federal constitutional decisions are a form of logical and institutional testing and experimentation. They are closer to the laboratory metaphor than many state initiatives that are not articulated, since these judicial experiments are published and subject to various forms of criticism and review, including potential review by federal courts.

Marc L. Miller \& Ronald F. Wright, Leaky Floors: State Law Below Federal Constitutional Limits, 50 ARIz. L. Rev. 227, 258 (2008).

68 See Charles Alan Wright \& Mary Kay Kane, Law of Federal Courts § 3, at 11 (7th ed. 2011) (describing the multi-state composition of federal regional circuits). In addition to affecting several states, circuit caselaw can affect outcomes in other circuits, by choice-of-law application, and even federal administrative proceedings (such as immigration). Logan, supra note 9, at 1163 \& n.162.

69 New State Ice Co. v. Liebmann, 285 U.S. 262, 310-11 (1932) (Brandeis, J., dissenting) (extolling the value of "experiments" undertaken "without risk to the rest of the country").

70 In addition, under such circumstances it is conceivable that a Tieboutian sorting benefit can accrue, as state residents can "vote with their feet" in pursuit of preferable positions adopted elsewhere. See Robert D. Cooter, The Strategic Constitution 


\section{State "Voice"}

A second major benefit concerns the unique perspective state courts bring to the job of federal constitutional interpretation and application. State courts not only have been engaged in constitutional interpretation for a far longer time than lower federal courts, ${ }^{71}$ they also process an exponentially higher volume of criminal cases than federal courts, ${ }^{72}$ affording them corresponding greater experience in the resolution of constitutional criminal procedure questions. ${ }^{73}$

State courts, moreover, operate within an institutional context that very often differs from their federal judicial counterparts. ${ }^{74}$ The difference is such that, to the extent that judicial decisionmaking is animated by what political scientists refer to as "team theory," 75 state courts operate from the perspective of a distinctly different team. ${ }^{76}$

Finally, unlike life-tenured federal judges, state judges most often stand for election, ${ }^{77}$ providing what Professor David Pozen has called a "systematic

127-29 (2000) (discussing local government competition and its possible consequences); Todd E. Pettys, Competing for the People's Affection: Federalism's Forgotten Marketplace, 56 VAnd. L. Rev. 329, 332 (2003).

71 See supra text accompanying notes $41-51$; see also Scott Douglas Gerber, A DisTINCT Judicial Power 243 (2011) (noting that state courts exercised their power of judicial review in the Founding era whereas federal courts did not do so until later in the 1800s).

72 See Dept. of Justice, NCJ 234184, Federal Justice Statistics, 2009, at 17 tbl. 14 (Dec. 2011) (noting that nationwide state and local law enforcement account for $99 \%$ of all arrests and $94 \%$ of felony convictions).

73 See Ohio v. Robinette, 519 U.S. 33, 40 (1996) (Ginsburg, J., concurring) (noting the "unique vantage point" state courts have in automobile stop cases); see also Shirley S. Abrahamson, Criminal Law and State Constitutions: The Emergence of State Constitutional Law, 63 TEx. L. REv. 1141, 1148-49 (1985) ("The sheer number of state criminal cases . . means that the state courts have many opportunities to rule on both federal and state constitutional issues.").

74 See Miller \& Wright, supra note 67, at 254 ("[S] tate supreme courts . . are not 'lower courts' . . . . They do not have the same obligations as members of a unified [federal] judiciary. State high courts sit atop their own culture . . . and [operate within] a different social reality that exerts some gravitational pull on the meaning of legal requirements."); Robert A. Schapiro, Judicial Deference and Interpretive Coordinacy in State and Federal Constitutional Law, 85 Cornell L. Rev. 656, 659 (2000) ("Unlike federal courts, state courts generally do defer to the constitutional judgments of other branches of government."). States do of course differ in the nature and extent of their inter-branch interactions. See Shirley S. Abrahamson \& Robert L. Hughes, Shall We Dance? Steps for Legislators and Judges in Statutory Interpretation, 75 MinN. L. Rev. 1045, 1059-75 (1991) (describing variations among states with regard to inter-branch interaction).

75 Sara C. Benesh \& Wendy L. Martinek, Context and Compliance: A Comparison of State Supreme Courts and the Circuits, 93 MarQ. L. Rev. 795, 798 (2009).

76 See id. at 801.

77 See Aaron-Andrew P. Bruhl, Hierarchy and Heterogeneity: How to Read a Statute in a Lower Court, 97 Cornell L. Rev. 433, 489 (2012) (noting that approximately 90\% of state trial and appellate judges face election of some kind); Neal Devins \& Nicole Mansker, Public Opinion and State Supreme Courts, 13 U. PA. J. Const. L. 455, 462 (2010) (noting that 
and pervasive mechanism for popular constitutionalism."78 "The brute fact of having to face the voters," as Professors Bruhl and Leib recently noted, "gives elected judges a strong motivation to understand how the public will receive their rulings."79 Many state judges, moreover, have themselves previously served as elected officials, which supplies a degree of "political savvy and comprehension." 80

The political responsiveness of state courts has of course long dominated discourse concerning their institutional competence to decide federal constitutional questions. Alexander Hamilton expressed the fear that state courts would be less likely to give full scope to federal rights that are unpopular locally, ${ }^{81}$ a view echoed many decades later in Professor Neuborne's classic article The Myth of Parity. ${ }^{82}$

Such political pressures would logically have quite significant impact in the criminal procedure realm given the common unpopularity of extending rights to criminal defendants. ${ }^{83}$ Adopting a right-restrictive position might also be seen as the "safest" position in the face of jurisprudential uncertainty, ${ }^{84}$ and adopting a right-restrictive position at variance with the federal

state supreme court justices are subject to election of some kind in at least thirty-nine states).

78 David E. Pozen, Judicial Elections as Popular Constitutionalism, 110 Colum. L. Rev. 2047, 2050 (2010).

79 Aaron-Andrew P. Bruhl \& Ethan J. Leib, Elected Judges and Statutory Interpretation, 79 U. Chr. L. Rev. 1215, 1250 (2012); see also Amanda Frost \& Stefanie A. Lindquist, Countering the Majoritarian Difficulty, 96 VA. L. REv. 719, 731-40 (2010) (surveying empirical work suggesting that state judges are more inclined to decide cases in line with popular opinion).

80 Bruhl \& Leib, supra note 79, at 1250.

81 See supra note 46. As also noted, however, Hamilton was prone to praise state courts for their independence and competence. See supra note 46.

82 See Neuborne, supra note 22, at 1131 ("[T] he only judicial forums . . capable of enforcing countermajoritarian checks in a sustained, effective manner are the federal courts . . . ."); see also A.L.I. Study of the Division of Jurisdiction Between State and Federal Courts, Commentary, General Diversity Jurisdiction, at 41 (Tent. Draft No. 1, 1963)) (surveying sources maintaining that "provincialism" and "local spirit" impede extension of federal rights in state courts); Amsterdam, supra note 22, at 802 (quoting THE Federalist No. 80, at 429 (Warner ed. 1818) (Alexander Hamilton)); Stephen P. Croley, The Majoritarian Difficulty: Elective Judiciaries and the Rule of Law, 62 U. CHI. L. REv. 689 (1995) (asserting that elected state judiciaries are prone to institutional bias against criminal defendants).

83 See Ronald F. Wright \& Wayne A. Logan, The Political Economy of Application Fees for Indigent Criminal Defense, 47 WM. \& Mary L. Rev. 2045, 2068 (2006); see also Devins \& Mansker, supra note 77, at 476-77 (noting that with the exception of criminal justice, and a few select other issue areas, "there is little reason to think that the public is aware of state supreme court decision making").

84 A sentiment exemplified by Illinois Court of Appeals Judge Robert English, who in the Warren Court era wrote:

I should not want to participate in the release of a convicted defendant on the basis of what the Supreme Court of the United States might do in the circum- 
judiciary could bolster support among state voters (such as in the desegregation-era South). ${ }^{85}$

Research, however, has not borne out the premise that state courts are reflexively hostile to federal constitutional criminal procedure rights. ${ }^{86}$ Historically, this does not appear to be the case, ${ }^{87}$ nor does it seem so based on the author's examination of Roberts Court cases reviewing state court criminal procedure decisions. ${ }^{88}$ Cases decided in an eight-year period (October Term 2005 to October Term 2012) highlight the varied positions adopted by state courts. ${ }^{89}$ Not surprisingly, state courts often adopted right-limiting positions, at times resulting in reversal, ${ }^{90}$ but more often affirmance by the Court. ${ }^{91}$ Yet, much as during the Warren Court era, when state courts were

stances were such a case to be presented to it, and then find out later that the

Court was disinclined to go quite that far.

Robert E. English, Lawyers in the Station House?, 57 J. Crim. L. Criminology \& Police Sci. 283, 283 (1966).

85 See Solimine \& Walker, supra note 55, at 35; John C. Kilwein \& Richard A. Brisbin, Jr., Policy Convergence in a Federal Judicial System: The Application of Intensified Scrutiny Doctrines by State Supreme Courts, 41 Am. J. Pol. Scr. 122, 131 (1997); see also Bruhl \& Leib, supra note 79 , at 1272 (" $[\mathrm{I}] \mathrm{t}$ is hard to believe that an elected judge primed to respond to constituents' views would ignore those views just because federal law is at issue.").

86 Cf. Brett Christopher Gerry, Parity Revisited: An Empirical Comparison of State and Lower Federal Court Interpretations of Nollan v. California Coastal Commission, 23 HaRv. J.L. \& Pub. Pol'y 233, 283-85 (1999) (surveying Takings Clause cases and concluding that little variation exists in receptivity to claims in state and federal court); William B. Rubenstein, The Myth of Superiority, 16 Const. Comment. 599, 599 (1999) (surveying state cases and concluding that "gay litigants seeking to establish and vindicate civil rights have generally fared better in state courts than they have in federal courts").

87 See Solimine \& Walker, supra note 55, at 50-54; Cf. James S. Liebman et al., Capital Attrition: Error Rates in Capital Cases, 1973-1995, 78 Tex. L. Rev. 1839, 1855 (2000) (noting that despite the common belief that federal judges are more likely to overturn capital cases than elected state judges, the latter accounted for $90 \%$ of cases overturned during study period, prompting the study's authors to conclude that "state judges are the first and most important line of defense against erroneous death sentences").

88 The survey consisted of cases collectively drawn from the SCOTUS Blog and the BNA Reporter.

89 The survey examined cases coming to the Court by direct appeal from a state court, $\S 1983$, and state post-conviction. It omitted federal habeas cases because the standard of federal review is so undemanding. See infra text accompanying notes 242-45; see also Renico v. Lett, 559 U.S. 766, 778 n.3 (2010) (stating that "whether the [state court] was right or wrong is not the pertinent question under the [Anti-Terrorism and Effective Death Penalty Act of 1996]").

90 See, e.g., J.D.B. v. North Carolina, 131 S. Ct. 2394, 2406 (2011) (reversing North Carolina Supreme Court's holding that a child's age, when known or reasonably known by police, does not warrant consideration in Miranda custody analysis); Brendlin v. California, 551 U.S. 249, 257 (2007) (reversing the California Supreme Court's holding that a traffic stop does not result in the seizure of a passenger).

91 See, e.g., Perry v. New Hampshire, 132 S. Ct. 716, 730 (2012) (affirming the New Hampshire Supreme Court's holding that eyewitness identification satisfies due process unless suggestive circumstances are arranged by police); Hudson v. Michigan, 547 U.S. 
often more protective of federal rights than lower federal courts, ${ }^{92}$ and the Burger Court era, ${ }^{93}$ when the Justices felt obliged to caution them against overenforcement, ${ }^{94}$ state courts staked out pro-defense positions. In several such instances, the Roberts Court reversed, ${ }^{95}$ even chiding them for their perceived excesses. ${ }^{96}$

However, there were also several notable instances in which the Court affirmed (and applied nationwide) a right-protective position adopted by a state court. ${ }^{97}$ For instance, in Georgia v. Randolph, the Court backed the deci-

586, 602 (2006) (affirming a Michigan Court of Appeals holding that police violation of "knock and announce" requirement does not trigger the exclusionary rule).

92 See Lawrence Gene Sager, Fair Measure: The Legal Status of Underenforced Constitutional Norms, 91 Harv. L. Rev. 1212, 1251-53 (1978); see also, e.g., Barnes v. State, 130 N.W.2d 264, 269 (Wis. 1964) (foreshadowing the position adopted by the Court in Arizona v. Gant, 556 U.S. 332 (2009), rejecting a police search incident to arrest authority based on a traffic violation arrest because no fruits tied to the arrest basis likely would be found).

93 See J. Skelly Wright, Jr., In Praise of State Courts: Confessions of a Federal Judge, 11 HasTINGS CoNST. L.Q. 165, 181-83 (1984).

94 See, e.g., Oregon v. Hass, 420 U.S. 714, 719 (1975) ("[A] State may not impose such greater restrictions [on police behavior] as a matter of federal constitutional law when this Court specifically refrains from imposing them." (emphasis omitted)).

95 See, e.g., Maryland v. King, 133 S. Ct. 1958, 1980 (2013) (reversing a Maryland Court of Appeals holding that barred warrantless DNA swabs of arrestees); Kentucky v. King, 131 S. Ct. 1849, 1862-63 (2011) (reversing the Kentucky Supreme Court and holding that police could "create an exigency" to enter a home so long as they act in a manner consistent with the Fourth Amendment); Florida v. Powell, 559 U.S. 50, 64 (2010) (reversing a Florida Supreme Court decision requiring that a Miranda warning contain express advice of defendant's entitlement to "presence" of counsel); Virginia v. Moore, 553 U.S. 164, 178 (2008) (reversing a Virginia Supreme Court holding that a violation of state law limiting arrest authority violated the Fourth Amendment); Brigham City v. Stuart, 547 U.S. 398, 406-07 (2006) (reversing a Utah Supreme Court holding that warrantless entry of home by police, based on emergency, must be motivated solely by a non-law enforcement function).

96 See, e.g., Florida v. Harris, 133 S. Ct. 1050, 1056 (2013) (reversing, by a 9-0 vote, the Florida Supreme Court, which "flouted" established law on probable cause analysis). For a pre-Roberts Court example, see Arkansas v. Sullivan, 532 U.S. 769 (2001). In Sullivan, which concerned application of Whren $v$. United States, 517 U.S. 806 (1996), holding that an officer's pretextual subjective motivation for making a stop is irrelevant so long as the facts objectively support a lawful basis, the Arkansas Supreme Court asserted that "there is nothing that prevents this court from interpreting the U.S. Constitution more broadly than the United States Supreme Court, which has the effect of providing more rights." Sullivan, 532 U.S. at 771 (quoting State v. Sullivan, 16 S.W.3d 551, 552 (Ark. 2000)) (internal quotation marks omitted). The Supreme Court reversed in a per curiam opinion, stating that the Arkansas Supreme Court's position was "flatly contrary to [the] Court's controlling precedent." Id. And, in a fit of seeming passive aggressiveness, it offered that the state court's belief that it could "provide greater protection than this Court's own federal constitutional precedents provide . . . surely must be an inadvertent error." Id. at 772 (citing Oregon v. Hass, 420 U.S. 714, 719 \& n.4 (1975)) (internal quotation marks omitted).

97 Affirmances of state court constitutional criminal procedure decisions, it should be noted, are themselves historically uncommon. See John C. Kilwein \& Richard A. Brisbin, Jr., U.S. Supreme Court Review of State High Court Decisions from the Warren Through the Rehnquist Courts, 89 Judicature 146, 148 (2005) (noting that on average the Warren, Burger, and Rehnquist Courts affirmed only $30 \%$ of state decisions). The Court as a general mat- 
sion of the Georgia Supreme Court that consent to enter a shared residence is invalid if a physically present resident objects. ${ }^{98}$ At the time, no federal court had so held, and the Georgia Supreme Court stood almost alone (sharing company with only the supreme courts of Florida, Minnesota and Washington). ${ }^{99}$ Similarly, in Arizona v. Gant, ${ }^{100}$ the Supreme Court affirmed the Arizona Supreme Court's outlier position, both nationally and vis-à-vis the Ninth Circuit, ${ }^{101}$ limiting police authority to search vehicles incident to arrest. ${ }^{102}$ And, in Florida v. Jardines, the Court backed the Florida Supreme Court's position that police use of a drug-detection dog to sniff the exterior of a home constituted a search, triggering Fourth Amendment protection $^{103}$ - a position rejected by the vast majority of state and almost all federal circuit courts. ${ }^{104}$

In short, far from constituting "needless conflict between state and federal courts," 105 the varied doctrinal positions adopted by state and lower federal courts serve as essential grist in the ongoing exposition of the nation's Constitution. ${ }^{106}$ Moreover, affording states in particular-sovereigns whose "dignity" is thought worthy of respect ${ }^{107}$ - a chance to be involved in the making of national constitutional law has a federalism-enforcing benefit. It allows buy-in, affording an avenue for what Professor Paul Bator termed "membership" in the nation's "cooperative moral and legal community."108

ter is far more prone to reverse than affirm. See Lee Epstein et al., The Supreme Court Compendium 271 (5th ed. 2012) (noting that in recent years the Court reverses $70-75 \%$ of cases argued).

98547 U.S. 103, 121-22 (2006).

99 See Petition for Writ of Certiorari at 8, Georgia v. Randolph, 547 U.S 103 (2006) (No. 04-1067), 2005 WL 309364, at *5 (citing Silva v. State, 344 So. 2d 559 (Fla. 1977); In re D.A.G., 484 N.W.2d 787 (Minn. 1992); State v. Leach, 782 P.2d 1035 (Wash. 1989)).

100556 U.S. 332 (2009).

101 See State v. Gant, 162 P.3d 640, 645 (Ariz. 2007) (noting that "most other courts" would allow search), aff'd, 556 U.S. 332 (2009).

102 Gant, 556 U.S. at 351 (allowing search only if the arrestee is within reaching distance of the vehicle or it is reasonable to believe that the vehicle contains evidence supporting basis for arrest).

103133 S. Ct. 1409, 1419 (2013).

104 Jardines v. State, 73 So. 3d 34, 66-68 \& nn.15-16 (Fla. 2011) (Polston, J., dissenting).

105 See Mapp v. Ohio, 367 U.S. 643, 657-58 (1961) (““[T] he very essence of a healthy federalism depends upon the avoidance of needless conflict between state and federal courts." (quoting Elkins v. United States, 364 U.S. 206, 221 (1960))).

106 See Jeremy Waldron, Stare Decisis and the Rule of Law: A Layered Approach, 111 MicH. L. REv. 1, 3 (2012) (emphasizing the judiciary's contributory role in creating the "framework of public norms").

107 See Alden v. Maine, 527 U.S. 706, 714 (1999); see also Danforth v. Minnesota, 552 U.S. 264, 280 (2008) ("States are independent sovereigns with plenary authority . . ..”).

108 Bator, supra note 19, at 635; see also Authority in State Courts, supra note 20, at 948 (explaining that state court "freedom to make their own decisions will eliminate any latent sentiment in the state courts that national law is in some way foreign to them"). 


\section{Praxis and Problems}

The story of state court empowerment just recounted, however, yields only a partial picture of the true significance of state court authority. This added significance comes into focus when one takes account of a key structural fact, noted at the outset: the authority of state courts to reject the constitutional positions of federal circuit courts, including those of the circuit in which they are located. ${ }^{109}$ This Part surveys how state courts go about exercising their constitutional autonomy and then discusses the practical problems that arise when state courts and their coordinate federal circuits disagree.

\section{A. State Approaches}

While in the past state courts often felt obliged to defer to the federal constitutional decisions of federal circuits, ${ }^{110}$ today at least forty-six states and the District of Columbia regard such decisions as non-binding and worthy of at most persuasive precedential weight. ${ }^{111}$ Typically, the courts assert their position in blanket, unequivocal terms. ${ }^{112}$ As the Montana Supreme Court flatly stated a decade ago, "[t]he Supremacy Clause does not require state courts to follow precedent from the circuit courts of appeal interpreting the United States Constitution." 113 And, while state courts at times voice a measure of greater receptivity to their own circuit's precedent, ${ }^{114}$ others pay it

109 See supra notes $15-17$ and accompanying text.

110 See, e.g., MacKenzie v. Hare, 134 P. 713, 714 (Cal. 1913) (noting that state courts are "bound by the interpretation put upon [the Constitution] by the courts of the United States"); People v. Wolfe, 147 N.W.2d 447, 550 (Mich. Ct. App. 1967) ("The standards in the federal cases control so far as the states are concerned, as a result of Mapp v. Ohio." (citation omitted)); see also Annotation, Duty of State Courts to Follow Decisions of Federal Courts, Other than the Supreme Court, on Federal Questions, 147 A.L.R. 857 (1943) (surveying state caselaw); Authority in State Courts, supra note 20, at 944 (" $[\mathrm{S}]$ tate courts have widely disagreed as to the binding effect of such decisions when made by the lower federal courts.").

111 See infra Appendix. Seemingly, only Delaware has adopted a policy of deference. See infra Appendix. In three states (Utah, Virginia, and Wyoming) it is difficult to specify a position with any degree of certainty. See infra Appendix.

112 See, e.g., State v. Sansing, 77 P.3d 30, 33 n.2 (Ariz. 2003) ("We are not bound by the Ninth Circuit's interpretation of what the Constitution requires.”); People v. Williams, 641 N.E.2d 296, 321 (Ill. 1994) ("[D] ecisions of lower Federal courts on Federal constitutional questions are not binding on State courts.”); State v. Sanders, 648 So. 2d 1272, 1279 (La. 1994) ("[L] ower federal court decisions do not bind this court's interpretations of federal constitutional law."); Strouth v. State, 999 S.W.2d 759, 765 n.9 (Tenn. 1999) (explaining that a state court is "not bound by decisions of the federal district and circuit courts"); State v. Mechtel, 499 N.W.2d 662, 666 (Wis. 1993) ("It is clear . . . that determinations on federal questions by either the federal circuit courts of appeal or the federal district courts are not binding upon state courts.").

113 State v. Robinson, 82 P.3d 27, 30 (Mont. 2003).

114 See State v. Smith, 881 A.2d 160, 181 n.15 (Conn. 2005) (deeming Second Circuit "particularly persuasive"); Holloway v. United States, 951 A.2d 59, 63 (D.C. 2008) (deeming the D.C. Circuit "highly persuasive" (citation omitted)); State v. Gardner, 509 A.2d 
little more than lip service ${ }^{115}$ or flatly reject that circuit dominion is relevant. ${ }^{116}$

The growth in state court autonomy signals an important shift in the nation's judiciary, one underscored by the work of social scientists examining state-federal court relations. Professor Laurence Benner and his colleagues, for instance, in reviewing state court cases decided from 1915 to 1936 regarding whether to adopt the federal exclusionary rule (mandated by Weeks $v$. United States), ${ }^{117}$ discovered a distinct circuit-centrism. ${ }^{118}$ They found that decisions adopting the exclusionary rule by other state courts located in the same federal circuit were key, having more influence than courts in a neighboring state or states situated in the same West reporter or census region. ${ }^{119}$ Building on prior research detecting a similar influence, ${ }^{120}$ the authors attributed the outcome to the enhanced communication within and influence of federal circuits. ${ }^{121}$ The findings reported here suggest operation of a far less pronounced federal circuit court impact.

At least as interesting is the contrast the findings have with the way state courts handle interpretation of their own state constitutions. Although enjoying the undisputed right to interpret their constitutions as they see fit, state courts very often interpret their constitutions in a manner that is in "lockstep" with the Supreme Court. ${ }^{122}$ The asymmetry allows for some curi-

1160, 1163 (Me. 1986) (deferring to the First Circuit "so far as reasonably possible"); Phillips v. Williams, 608 P.2d 1131, 1135 (Okla. 1989) (finding the Tenth Circuit "highly persuasive").

115 The Ohio Supreme Court, for instance, affords Sixth Circuit caselaw only "some persuasive weight." State v. Burnett, 755 N.E.2d 857, 862 (Ohio 2001).

116 See, e.g., Macias v. Cnty. of L.A., 50 Cal. Rptr. 3d 364, 371 n.5 (Ct. App. 2006) (“[W]e accord the decisions of the Ninth Circuit no greater weight than those of other circuits."); Feis v. King Cnty. Sheriff's Dep't, 267 P.3d 1022, 1034 (Wash. Ct. App. 2011), review denied, 277 P.3d 669 (Wash. 2012) (“'[T] he geographical location of the court issuing the opinion is of no moment.... We have never held that an opinion from the Ninth Circuit is more or less persuasive than, for example, the Second, Sixth, Seventh, Eighth, or Tenth Circuits." (quoting S.S. v. Alexander, 177 P.3d 724, 733 (Wash. Ct. App. 2008))).

117232 U.S. 383 (1914).

118 See Laurence A. Benner et al., Social-Network Theory and the Diffusion of the Search-andSeizure Exclusionary Rule Among State Courts Between Weeks and Wolf, 27 BYU J. PuB. L. 97 (2012).

119 Id. at 106.

120 See Robert C. Bird \& Donald J. Smythe, The Structure of American Legal Institutions and the Diffusion of Wrongful-Discharge Laws, 1978-1999, 42 Law \& Soc'Y Rev. 833 (2008); Robert A. Carp, The Scope and Function of Intra-Circuit Judicial Communication: A Case Study of the Eighth Circuit, 6 Law \& Soc'y Rev. 405 (1972); Ronald Stidham \& Robert A. Carp, Exploring Regionalism in the Federal District Courts, 18 Publius 113 (1988).

121 Benner et al., supra note 118, at 136; see also id. at 139 ("[A] state supreme-court decision from another jurisdiction that adopted the rule appeared to be more persuasive if that state was within the same federal circuit as the state considering such adoption.").

122 See generally Robert F. Williams, State Constitutional Methodology in Search and Seizure Cases, 77 Miss. L.J. 225, 249-51 (2007). And even when professing to undertake independent constitutional interpretation, state courts very often really do so in name only, engaging in what one commentator has termed "counterfeit" analysis. Francis Barry McCarthy, 
ous outcomes. In California, for example, state courts defer to federal wisdom (from the U.S. Supreme Court) on how to interpret their state constitution, ${ }^{123}$ yet disregard lower federal court wisdom when it comes to interpreting the U.S. Constitution. ${ }^{124}$ Although Supreme Court decisions obviously bear greater precedential weight than those of lower federal courts, the ready resistance of California courts to their lower federal counterparts on federal constitutional questions is nonetheless noteworthy. ${ }^{125}$ Whether it to some degree perhaps reflects a tit-for-tat institutional response based on rejection of one another's decisions more generally, ${ }^{126}$ or offense taken at the common federal disregard of state constitutional doctrine (from the Supreme Court on down), ${ }^{127}$ is a provocative question to ponder.

Finally, it should not go unmentioned that state court autonomy is selective; it does not extend to all federal legal questions. Although states typically ignore lower federal court wisdom on federal constitutional questions, they often defer to federal courts on the interpretation of federal statutes. Illinois, for instance, gives "considerable weight" to and finds "highly persuasive" federal court interpretations of federal statutes, but goes its own way on constitutional questions. ${ }^{128}$ Deference is needed "in the interest of preserving unity" because "uniformity of decision is an important consideration when state courts interpret federal statutes."129

Counterfeit Interpretations of State Constitutions in Criminal Procedure, 58 SyRACuse L. Rev. 79 passim (2008).

123 See James A. Gardner, The Failed Discourse of State Constitutionalism, 90 Mich. L. Rev. 761, 790 (1992).

124 See, e.g., People v. Williams, 299 P.3d 1185, 1214 (Cal. 2013) ("[D]ecisions by the federal courts of appeal are not binding on us."); People v. Gray, 118 P.3d 496, 536 (Cal. 2005) ("We are, of course, not bound by the decisions of lower federal courts.").

125 See, e.g., Williams, 299 P.3d at 1214.

126 See, e.g., Ruth A. Moyer, Why and How a Lower Federal Court's Decision That a Search or Seizure Violated the Fourth Amendment Should Be Binding in a State Prosecution: Using "Good Sense" and Suppressing Unnecessary Formalism, 36 VT. L. REv. 165, 206 (2011) (suggesting that such a sentiment is operable when, in instances of successive prosecutions, state and federal courts disregard one another's prior suppression decisions).

127 See Joseph Blocher, Reverse Incorporation of State Constitutional Law, 84 S. CAL. L. REv. 323, 346 (2011) ("State courts appear to be holding up their end of th[e] arrangement (perhaps with too much enthusiasm) by borrowing heavily from federal doctrine. Federal courts, on the other hand, generally are not.").

128 Compare State Bank of Cherry v. CGB Enters., Inc., 984 N.E.2d 449, 458-59 (Ill. 2013) (deferring to lower federal courts when the courts agree on interpretation of a federal statute), with People v. Brisbon, 544 N.E.2d 297, 308 (Ill. 1989) (rejecting deference to federal courts on federal constitutional questions).

129 State Bank of Cherry, 984 N.E.2d at 459; see also Weatherford v. State, 81 P.3d 320, 324 (Ariz. 2003) (en banc) (stating that deferring on federal statutory interpretation questions "furthers federal-state . . relations[ ]"); NRDC v. Dep't of Envtl. Quality, 832 N.W.2d 288, 295 (Mich. Ct. App. 2013) ("Unless there is a conflict among federal courts [on the statutory question], this Court is bound by the holdings of federal courts on federal questions."). State court deference to federal lower court wisdom is also seen in the context of maritime law. See Royal Caribbean Cruises, Ltd. v. Cox, 137 So. 3d 1157, 1161 (Fla. Dist. 
The reason for the dichotomy has gone unstated but might rest on the logic that federal statutory law, unlike federal constitutional law, is the handiwork of Congress, and state courts should therefore defer much as federal courts defer to state court interpretations of state substantive law under Erie v. Tompkins Railroad. ${ }^{130}$ Yet, even if this is correct, it remains unclear why the practical effect of disuniformity should warrant special concern with federal statutory but not constitutional law, ${ }^{131}$ when if anything the converse should be the case. ${ }^{132}$

\section{B. The Conflicts and Their Consequences}

When operationalized, state and lower federal court power to disagree gives rise to a considerable number of intrastate criminal procedure conflicts. With respect to Fourth Amendment limits on the search authority of police, conflicts exist on such basic questions as what qualifies as a "search"133 and whether the Court's recent decision in Arizona v. Gant, ${ }^{134}$ limiting police authority to search a car's interior when an arrestee has been secured, extends to the non-auto context. ${ }^{135}$ Conflicts also exist on whether police can:

- conduct a warrantless safety "sweep" of a home in situations other than when an in-home arrest occurs ${ }^{136}$

Ct. App. 2014) (noting that although it was not bound by federal lower court decisions the federal interest in "harmony" and "uniformity" in maritime law dictates deference).

130 See Clermont, supra note 23, at 31 ("In both the Erie setting and the reverse-Erie setting, the court's job is to apply the other sovereign's law, not to create law for it."); Omar K. Madhany, Comment, Towards a Unified Theory of "Reverse-Erie," 162 U. PA. L. REv. 1261, 1299 (2014) (positing that federal courts are best situated to divine federal congressional intent).

131 Except of course when Congress explicitly seeks uniformity in the interpretation and application of its statutes. See, e.g., Allis-Chalmers Corp. v. Lueck, 471 U.S. 202, 211 (1985) (noting the need for interpretive uniformity in the interpretation of collective bargaining agreements in litigation brought under the Federal Labor Management Relations Act).

132 See infra note 297 and accompanying text.

133 Compare United States v. \$277,000 U.S. Currency, 941 F.2d 898, 899 (9th Cir. 1991) (holding that police performed a search by removing a tarp covering a truck in the backyard of a residence), with State v. Allen, 166 P.3d 111, 116 (Ariz. Ct. App. 2007) (rejecting the Ninth Circuit position), cert. denied, 555 U.S. 817 (2008).

134556 U.S. 332 (2009).

135 Compare United States v. Carter, 520 F. App’x 377, 381-82 (6th Cir. 2013) (extending Gant), cert. denied, 134 S. Ct. 247 (2013), with Robbins v. Commonwealth, 336 S.W.3d 60, 64 (Ky. 2011) (declining to extend Gant); compare United States v. Perdoma, 621 F.3d 745, 751-52 (8th Cir. 2010) (declining to extend Gant), cert. denied, 131 S. Ct. 2446 (2011), with State v. Lussier, 770 N.W.2d 581, 589 (Minn. Ct. App. 2009) (extending Gant).

136 Compare United States v. Taylor, 248 F.3d 506, 513 (6th Cir. 2001) (“[T] he principle enunciated in Buie... applies with equal force to an officer left behind to secure the premises while a warrant to search those premises is obtained."), cert. denied, 534 U.S. 981 
- enter a home without a warrant based on the "community caretaking" doctrine $^{137}$ or to preserve evidence regarding an individual suspected of driving while intoxicated ${ }^{138}$

- perform a protective frisk for weapons in a consensual encounter lacking in any evidence of unlawful activity by the seized individual ${ }^{139}$

- enter a home without a warrant or probable case when acting to address an emergency or safety concern of an inhabitant ${ }^{140}$

- search a container when, acting on consent provided by one with apparent authority, uncertainty arises over the container's ownership $^{141}$

(2001), with Guzman v. Commonwealth, 375 S.W.3d 805, 807-08 (Ky. 2012) (holding that under Buie an officer may only conduct a protective sweep in conjunction with a lawful arrest); compare United States v. Torres-Castro, 470 F.3d 992, 997 (10th Cir. 2006) (declining to extend Buie and reaffirming its previous decisions that " a protective sweep may only be performed incident to an arrest'" (citation omitted)), cert. denied, 550 U.S. 949 (2007), with People v. Strimple, 267 P.3d 1219, 1220-21 (Colo. 2012) (en banc) (upholding a warrantless protective sweep when entry was premised on consent).

137 Compare United States v. Erickson, 991 F.2d 529, 531 (9th Cir. 1993) (disallowing warrantless entry of home based on the community caretaking doctrine), with People v. Ray, 981 P.2d 928, 938 (Cal. 1999) (allowing warrantless entry), cert. denied, 528 U.S. 1187 (2000).

138 Compare Hopkins v. Bonvicino, 573 F.3d 752, 769 (9th Cir. 2009) (disallowing warrantless entry, relying on "felony/misdemeanor distinction" adopted in Welsh v. Wisconsin, 466 U.S. 740, 753 (1984)), cert. denied, 559 U.S. 1048 (2010), with People v. Thompson, 135 P.3d 3, 9 (Cal. 2006) (allowing warrantless entry, distinguishing Welsh v. Wisconsin because California (unlike Wisconsin) made DUIs a jailable offense).

139 Compare United States v. Orman, 486 F.3d 1170, 1173 (9th Cir. 2007) (allowing frisk in absence of lawful seizure), with State v. Serna, 331 P.3d 405, 410 (Ariz. 2014) (expressly rejecting the Ninth Circuit position); compare United States v. Burton, 228 F.3d 524, 528 (4th Cir. 2000) (stating that in a consensual encounter "an officer may not conduct [a] protective search for purposes of safety until he has a reasonable suspicion [of criminal activity]"), with Bailey v. State, 987 A.2d 72, 83 (Md. 2010) (explaining that an "articulable suspicion to believe that criminal activity [is] afoot" is not necessary in order to conduct a protective pat-down search during a consensual encounter).

140 Compare Huff v. City of Burbank, 632 F.3d 539, 548-49 \& n.3 (9th Cir. 2011) (declining to merge the emergency and exigent circumstances doctrines and holding that when an officer acts in an investigatory capacity, a warrantless search is valid only with probable cause and exigent circumstances), rev'd on other grounds sub nom., Ryburn v. Huff, 132 S. Ct. 987 (2012), with Hannon v. State, 207 P.3d 344, 346-47 (Nev. 2009) (merging the emergency and exigent circumstances doctrines and construing Brigham City v. Stuart, 547 U.S. 398 (2006), to dispense with the probable cause requirement in an emergency or safety situation even if officer is acting in an investigatory capacity).

141 Compare United States v. Snype, 441 F.3d 119, 136 (2d Cir. 2006) (holding that a search premised on apparent authority extends to all items, including closed containers, except those “"obviously' belonging to another person”), cert. denied, 549 U.S. 923 (2006), with People v. Gonzalez, 667 N.E.2d 323, 327 (N.Y. 1996) (holding that when faced with ambiguity over ownership of a closed container, a search may not proceed without further inquiry); compare United States v. Melgar, 227 F.3d 1038, 1041-42 (7th Cir. 2000) (declining to adopt the bright-line rule that ambiguity of ownership requires further inquiry prior to a consensual search based on apparent authority), with Norris v. State, 732 N.E.2d 186, 
- enter, without a search warrant, the common area of an apartment or other multi-dwelling unit to conduct an investigation ${ }^{142}$

- conduct a pat-down search of all companions of arrestees (the "automatic companion" rule) ${ }^{143}$

- search a non-occupant visitor's belongings pursuant to a search warrant for a home ${ }^{144}$

- enter a suspect's home without probable cause to believe that the suspect is at home when executing an arrest warrant. ${ }^{145}$

Fourth Amendment doctrine on the power of law enforcement to seize individuals is marked by similar conflicts, with differences existing on whether police can:

- stop an individual based on reasonable suspicion that they have committed a past misdemeanor (versus a past felony) ${ }^{146}$

191 (Ind. Ct. App. 2000) ("[U]nder a sound application of the apparent authority rule the police must be required to make reasonable inquiries when they find themselves in ambiguous circumstances." (quoting 3 Wayne R. LaFave, Search and Seizure $\$ 8.3(\mathrm{~g})$, at 267 (2d ed. 1987)) (internal quotation marks omitted)).

142 Compare United States v. Heath, 259 F.3d 522, 534 (6th Cir. 2001) (adopting a per se rule that the tenant of an apartment building has a per se reasonable expectation of privacy), with State v. Talley, 307 S.W.3d 723, 734 (Tenn. 2010) (rejecting the Sixth Circuit position and adopting a totality of the circumstances test), cert. denied, 131 S. Ct. 187 (2010).

143 Compare United States v. Poms, 484 F.2d 919, 922 (4th Cir. 1973) (adopting rule), with El-Amin v. Commonwealth, 607 S.E.2d 115, 118 (Va. 2005) (noting and rejecting the Fourth Circuit's contrary position); compare United States v. Bell, 762 F.2d 495, 498-99 (6th Cir. 1985) (declining to adopt the rule), with Owens v. Commonwealth, 291 S.W.3d 704, 709 n.23 (Ky. 2009) (noting and rejecting the Sixth Circuit's contrary position).

144 Compare United States v. McLaughlin, 851 F.2d 283, 287 (9th Cir. 1988) (adopting a "relationship to the premises" test), with State v. Gilstrap, 332 P.3d 43, 46 (Ariz. 2014) (rejecting the Ninth Circuit approach and adopting a "possession" test, allowing police to search the personal belongings not in one's actual physical possession).

145 Compare United States v. Gorman, 314 F.3d 1105, 1112 (9th Cir. 2002) (holding that police must have probable cause, not a lesser quantum of evidence, to believe that a suspect lives in a residence and is inside at the time of entry), with People v. Downey, 130 Cal. Rptr. 3d 402, 408 (Ct. App. 2011) (rejecting the novel interpretation of the Ninth Circuit, the only circuit to require probable cause).

146 Compare United States v. Hughes, 517 F.3d 1013, 1017 (8th Cir. 2008) (declining to adopt a bright-line rule prohibiting stops for completed misdemeanors, stating that the "court must balance the "nature and quality of the intrusion on personal security against the importance of the governmental interests alleged to justify the intrusion'" (quoting United States v. Hensley, 469 U.S. 221, 228 (1985))), with Blaisdell v. Comm'r Pub. Safety, 375 N.W.2d 880, 883-84 (Minn. Ct. App. 1985) (deeming such stops unconstitutional), aff'd, 381 N.W.2d 849 (Minn. 1986); compare Gaddis ex rel. Gaddis v. Redford Twp., 364 F.3d 763, 771 n.6 (6th Cir. 2004) (prohibiting stops for completed misdemeanors), with State v. Blankenship, 757 S.W.2d 354, 356-57 (Tenn. Crim. App. 1988) (declining to adopt a bright-line rule prohibiting such stops). 
- enter a home without a warrant in "hot pursuit" to arrest a fleeing misdemeanant (as opposed to a felon) ${ }^{147}$

- search or arrest a motorist after a canine alerts to the presence of drugs in his car, when the ensuing search yields no drugs ${ }^{148}$

- conduct an auto checkpoint, resulting in discovery of criminal activity, without authorization by an elected official ${ }^{149}$

- retain a motorist's license without qualifying as a seizure. ${ }^{150}$

Intrastate disputes also exist on basic questions of Fourth Amendment standing to challenge conduct by law enforcement. ${ }^{151}$

State and lower federal courts within the same federal circuit also differ on Fifth and Sixth Amendment questions. For example, with the Fifth Amendment, they disagree on the application of the "question first, Mirandize later" test announced by the Court in Missouri v. Seibert, ${ }^{152}$ splitting over whether the plurality's multi-factor test or Justice Kennedy's concurring opinion (requiring subjective intent by police to avoid Miranda) is the rule. ${ }^{153}$ They also disagree on whether a Terry stop ${ }^{154}$ or handcuffing during

147 Compare Mascorro v. Billings, 656 F.3d 1198, 1207 (10th Cir. 2011) (holding that warrantless entry was not justified by hot pursuit doctrine in order to arrest a suspect for a "traffic misdemeanor"), with State v. Hamilton, 710 P.2d 174, 175 (Utah 1985) (upholding warrantless entry onto a suspect's property when "the officer was literally in 'hot pursuit' of a person who had been observed committing an offense, albeit a [traffic misdemeanor]"). 148 Compare United States v. Anchondo, 156 F.3d 1043, 1045-46 (10th Cir. 1998) (upholding the warrantless search and arrest of a motorist under such circumstances), with State v. Anderson, 136 P.3d 406, 415 (Kan. 2006) (rejecting the Tenth Circuit's position, endorsed by only one other court among many addressing the issue).

149 Compare Brouhard v. Lee, 125 F.3d 656, 660 (8th Cir. 1997) (holding that policeoperated auto checkpoints must be authorized by publicly elected official), with Sheridan v. State, 247 S.W.3d 481, 484 (Ark. 2007) (rejecting the Eighth Circuit's position).

150 Compare United States v. Thompson, 712 F.2d 1356, 1359-60 (11th Cir. 1983) (holding that a seizure occurs when an officer retains an individual's driver's license), with Golphin v. State, 945 So. 2d 1174, 1187-88 (Fla. 2006) (declining to adopt the Eleventh Circuit's bright-line rule and holding a seizure did not occur in light of the totality of the circumstances), cert. denied, 552 U.S. 810 (2007).

151 Compare United States v. Roper, 918 F.2d 885, 887-88 (10th Cir. 1990) (holding that an unauthorized driver of a rental car does not have standing to challenge the legality of a search), with State v. Bass, 300 P.3d 1193, 1200-01 (Okla. Crim. App. 2013) (rejecting the Tenth Circuit's position); compare United States v. Boruff, 909 F.2d 111, 117 (5th Cir. 1990) (stating that an unauthorized driver does not have standing), with Parker v. State, 182 S.W.3d 923, 926-27 (Tex. Crim. App. 2006) (noting and rejecting the Fifth Circuit's position); compare United States v. Thomas, 447 F.3d 1191, 1199 (9th Cir. 2006) (holding that an unauthorized driver has standing), with State v. Cutler, 159 P.3d 909, 911-12 (Idaho Ct. App. 2007) (noting and rejecting the Ninth Circuit position).

152542 U.S. 600 (2004).

153 Compare United States v. Street, 472 F.3d 1298, 1313-14 (11th Cir. 2006) (adopting the test urged by Justice Kennedy requiring finding of officer's subjective intent to avoid Miranda requirements), with State v. Pye, 653 S.E.2d 450, 453 n.6 (Ga. 2007) (rejecting that position). 
the execution of a search warrant ${ }^{155}$ qualifies as "custody" sufficient to trigger Miranda requirements. In the Sixth Amendment context, conflict exists on questions such as the factors used to determine when an individual becomes a "government agent" sufficient to trigger the Amendment's protections. ${ }^{156}$

The conflicts noted above highlight the long-ignored but quite extensive empiric reality of state-federal constitutional disuniformity within individual states. They also, as discussed next, have a variety of important real-world consequences.

\section{Rule of Law}

Perhaps most significant, the conflicts undercut basic rule of law expectations. Allowing the content of national constitutional law to depend on the uniform worn by a particular government agent or whether a case is filed in state or federal court is at odds with the core expectation of horizontal consistency in the law's content and application. ${ }^{157}$ As Professor Daniel Meador has observed:

One of the most basic features of law is that it embodies a set of rules and principles applicable to everyone in like manner throughout the jurisdiction it purports to govern. A judicial system that produces legal doctrine differing because of the happenstance of the place of litigation and of the particular judges sitting on the case is hostile to the reign of law. ${ }^{158}$

Concern over rights inconsistency, it might be offered, is unwarranted given the constitutional variation that already exists as a result of state court

154 Compare United States v. Newton, 369 F.3d 659, 673 (2d Cir. 2004) (rejecting the position that the Terry seizure analysis drives Miranda analysis), cert. denied, 549 U.S. 947 (2004), with State v. Torres, 500 A.2d 1299, 1302 (Conn. 1985) (employing the Terry analysis in assessing whether the defendant was in custody); compare United States v. Leshuk, 65 F.3d 1105, 1109-10 (4th Cir. 1995) (concluding that when a Terry stop is reasonable under the Fourth Amendment a suspect is not in custody for Miranda purposes), with Longshore v. State, 924 A.2d 1129, 1146 (Md. 2007) (rejecting the position that Terry seizure and Miranda custody analyses are synonymous).

155 Compare United States v. Bullard, No. 95-5785, 1996 WL 683790, at *6 (4th Cir. Nov. 27, 1996) (holding that handcuffed defendant was in custody), with Smith v. State, 974 A.2d 991, 1012-13 (Md. Ct. Spec. App. 2009) (adopting the contrary view); compare United States v. Cavazos, 668 F.3d 190, 194 (5th Cir. 2012) (holding that a handcuffed defendant was in custody), with State v. Palmer, 14 So. 3d 304, 310 (La. 2009) (adopting the contrary view).

156 Compare United States v. LaBare, 191 F.3d 60, 65 (1st Cir. 1999) (holding that for a Sixth Amendment right to be triggered a government cooperation agreement must specifically target the defendant), with Commonwealth v. Murphy, 862 N.E.2d 30, 40 (Mass. 2007) (rejecting the First Circuit's position).

157 See Frank B. Cross, Shattering the Fragile Case for Judicial Review of Rulemaking, 85 VA. L. REv. 1243, 1249 (1999) ("A central feature of the rule of law is its horizontal consistency of application.").

158 Daniel J. Meador, A Challenge to Judicial Architecture: Modifying the Regional Design of the U.S. Courts of Appeal, 56 U. CHI. L. REv. 603, 639 (1989). 
power to interpret state constitutions more generously than the federal constitution. ${ }^{159}$ Here, however, courts disagree over rights contained (or not) in the same constitution, one that controls in state and federal courts and regardless of whether the action of state or federal law enforcement agents is challenged. ${ }^{160}$

Under such circumstances, as the Supreme Court has warned, individuals "cannot know the scope of [their] constitutional protection." 161 They lack advance knowledge of their liberty and privacy rights and the parameters of government power to investigate and intrude on their lives. ${ }^{162}$ State-federal court conflicts, moreover, have an impact that is greater than the sum of their individual parts. They create what is effectively a constitutional prism in a state, ${ }^{163}$ and perhaps even several states within a given circuit when state courts themselves differ with one another and their circuit, ${ }^{164}$ magnifying in corresponding degree concern over governmental consistency and evenhandedness. ${ }^{165}$

159 See supra notes 122-23 and accompanying text.

160 See Head v. State, 322 S.E.2d 228, 231 (Ga. 1984) ("[W]e must acknowledge that while this court is not bound by the rulings of the federal court of appeals for our circuit, the citizens of this state, including prison officials, are most assuredly bound by the orders emanating from such rulings.").

161 New York v. Belton, 453 U.S. 454, 459-60 (1981); see also State v. Kock, 725 P.2d 1285, 1287 (Or. 1986) (averring that citizens "have their constitutional rights spelled out as clearly as possible"); $c f$. Planned Parenthood of Se. Pa. v. Casey, 505 U.S. 833, 844 (1992) (plurality opinion) ("Liberty finds no refuge in a jurisprudence of doubt.").

162 In the context of Miranda doctrine, as a dissenting member of the California Supreme Court said in relation to the majority's adoption of a less protective position than that adopted by the Ninth Circuit, the conflict both "invites forum shopping ... and causes confusion for anyone arrested in California on a question that is always important: If I remain silent, can my silence be used against me or not?" People v. Tom, 331 P.3d 303, 324 (Cal. 2014) (Liu, J., dissenting).

163 It is worth noting that the current uncertainty would have been heightened had states such as California been segmented into two or more circuits, as once proposed to reduce especially heavy circuit caseloads. See generally Arthur D. Hellman, Legal Problems of Dividing a State Between Federal Judicial Circuits, 122 U. PA. L. Rev. 1188 (1974).

164 For example, with respect to the criteria used to determine whether police justifiably entered a home without a search warrant based on concern that evidence might be destroyed, compare United States v. Mongold, 528 F. App’x 944, 949 (10th Cir. 2013) (specifying four factors to consider, including that a "serious crime" is involved), with People v. Wehmas, 246 P.3d 642, 649 (Colo. 2010) (en banc) (specifying four factors to consider but omitting mention of crime seriousness and adding, unlike the Tenth Circuit, that persons likely must be aware of police presence), and State v. Maxwell, 275 P.3d 220, 224 (Utah 2011) (applying a general reasonableness test). See also, e.g., State v. Gilstrap, 332 P.3d 43, 45-46 (noting, with respect to the question of whether police can search the belongings of a visitor at a residence, the position adopted by Arizona and Oregon courts conflicts with that of Alaska, California, and Hawaii courts, all of which differ from the position adopted by the Ninth Circuit).

165 See Friederich A. Hayek, The Road to Serfdom 72 (1944) ("Stripped of all [its] technicalities, [the rule of law] means that government in all its actions is bound by rules fixed and announced beforehand-rules which make it possible to foresee . . . how . . . authority will use . . coercive powers in given circumstances . . . ."); JERRY L. MASHAW, 
Of no less practical importance, intrastate variation creates the risk of forum shopping by government prosecutors. When a state and federal court adopt different positions it can be outcome-determinative whether (i) state/ local police or federal agents develop the case against a suspect ${ }^{166}$ and (ii) in an instance of concurrent criminal jurisdiction, whether a matter is filed in state or federal court. ${ }^{167}$ Faced with the prospect of having evidence suppressed in one court but not another, governments have a powerful incentive to seek out more advantageous doctrine, ${ }^{168}$ aggravating law-avoidance already occurring when cases "go federal" in an effort to avoid application of a more generous state constitutional right. ${ }^{169}$ To the extent that such strategic behavior undermines perception of government (writ large) cutting square corners, ${ }^{170}$ the procedural justice literature suggests an attendant decrease in the public's sense of governmental legitimacy and its willingness to be law-abiding. ${ }^{171}$

\section{Civil Rights Litigation}

The conflicts can also affect civil rights litigation. Under $\$ 1983$, officers enjoy personal qualified immunity from damage suits except when they violate "clearly established" constitutional law and are "plainly incompetent."172 Although it was long the case that a state-federal conflict put law enforcement in the unenviable position of facing monetary liability for complying

Greed, Chaos, and Governance 138-39 (1997) (defining rule of law as "a system of objective and accessible commands, law which can be seen to flow from collective agreement rather than from the exercise of discretion or preference by those ... who happen to be in positions of authority").

166 On the phenomenon more generally, see Wayne A. Logan, Dirty Silver Platters: The Enduring Challenge of Intergovernmental Investigative Illegality, 99 IowA L. Rev. 293 (2013).

167 See Wayne A. Logan, Erie and Federal Criminal Courts, 63 Vand. L. Rev. 1243, 1245 (2010).

168 See George C. Thomas III, Judges Are Not Economists and Other Reasons to Be Skeptical of Contingent Suppression Orders: A Response to Professor Dripps, 38 Aм. Crim. L. Rev. 47, 51 (2001) (discussing the influence of possible exclusion on filing decisions).

169 See Logan, supra note 166, at 320. A predisposition, it should not go unmentioned, that itself often goes unmediated by state prosecutorial desire to retain jurisdiction. See Rachel E. Barkow, Federalism and Criminal Law: What the Feds Can Learn from the States, 109 Mich. L. REv. 519, 577 (2011) ("Local prosecutors are typically quite happy to have federal prosecutors take on local cases so that defendants receive longer sentences, and they often willingly use the prospect of federal prosecution to gain leverage in their own plea negotiations with defendants. Local police officers also often prefer the federal option for the same reasons." (footnote omitted)).

170 See Allen v. McCurry, 449 U.S. 90, 116 (1980) (Blackmun, J., dissenting) ("The criminal defendant is an involuntary litigant ....").

171 See, e.g., Tom R. Tyler \& Yuen J. Huo, Trust in the Law 101-02 (2002); Tom R. Tyler \& Jeffrey Fagan, Legitimacy and Cooperation: Why Do People Help the Police Fight Crime in their Communities?, 6 OHIO Sт. J. CRIм. L. 231, 240 (2008).

172 Ashcroft v. al-Kidd, 131 S. Ct. 2074, 2085 (2011). 
with a position adopted by their employer-government's court, ${ }^{173}$ recent Supreme Court precedent has clarified that when a conflict exists and an officer acts in accord with her jurisdiction's doctrinal position, clearly established law cannot be said to have been violated. ${ }^{174}$ The newly clarified position, however, comes at a cost: a right, recognized by either state or federal court, goes unenforced. ${ }^{175}$

Conflict can also have a critical impact on less core yet still important matters in civil rights litigation. A prime example lays in varied judicial positions on whether a particular government actor qualifies as a "state" agent sufficient to bar suit under the Eleventh Amendment. ${ }^{176}$ The California Supreme Court, for instance, has held that a county sheriff is a state agent for purposes of $\S 1983$, barring suit; ${ }^{177}$ the Ninth Circuit disagrees, and so will entertain a claim against a county sheriff. ${ }^{178}$ Because federal civil rights claims can be filed in state or federal court, ${ }^{179}$ the specter of forum shopping again looms, this time among plaintiffs (not prosecutors).

173 See, e.g., Hopkins v. Bonvicino, 573 F.3d 752, 772 (9th Cir. 2009) (“[A] decision by a state court contrary to a holding of this court cannot unsettle or 'de-establish' the clarity of federal law. ... 'If the right is clearly established by decisional authority of the Supreme Court or this Circuit, our inquiry should come to an end.'”) (quoting Boyd v. Benton Cnty., 374 F.3d 773, 781 (9th Cir. 2004)); see also Richard H. Fallon, Jr. \& Daniel J. Meltzer, New Law, Non-Retroactivity, and Constitutional Remedies, 104 Harv. L. Rev. 1731, 1751 n.105 (1991) ("Questions about whether federal courts should treat precedents from state courts as clearly establishing the law (and vice versa) obviously add substantial complexity [to the qualified immunity analysis]."); Richard B. Saphire, Qualified Immunity in Section 1983 Cases and the Role of State Decisional Law, 35 Ariz. L. Rev. 621, 627-34 (1993) (surveying state and lower federal court positions on the question, and noting that state courts on occasion looked to federal law but not vice versa).

174 See Stanton v. Sims, 134 S. Ct. 3, 7 (2013) (noting that it was "especially troubling that the Ninth Circuit would conclude that [the defendant state officer] was plainly incompetent-and subject to personal liability for damages-based on actions that were lawful according to courts in the jurisdiction where he acted"); (f. al-Kidd, 131 S. Ct. at 2086 (Kennedy, J., concurring) ("When faced with inconsistent legal rules in different jurisdictions, national officeholders should be given some deference for qualified immunity purposes, at least if they implement policies consistent with the governing law of the jurisdiction where the action is taken.").

175 See John C. Jeffries, Jr., Reversing the Order of Battle in Constitutional Torts, 2009 Sup. Ст. Rev. 115, 131 (noting that willingness of courts to deem a right unsettled results in "the underenforcement of constitutional rights while such uncertainty continues.").

176 See John C. Jeffries, Jr., The Liability Rule for Constitutional Torts, 99 VA. L. Rev. 207, 207-08 (2013) ("The right being enforced is irrelevant to constitutional tort doctrine. What matters instead is the identity of the defendant . . . States and state agencies are absolutely immune from damages liability for violations of constitutional rights, no matter how egregious their conduct may be.").

177 Venegas v. Cnty. of L.A., 87 P.3d 1, 21 (Cal. 2004).

178 Nelson v. Cnty. of Sacramento, 926 F. Supp. 2d 1159, 1167 (E.D. Cal. 2013) (noting the tension).

179 See Saphire, supra note 173 ("[P]laintiffs who wish to litigate section 1983 claims have a choice of filing suit in state or federal court.”). 


\section{3. "Good Faith" and the Exclusionary Rule}

Finally, variability can affect trial court decisions on the exclusion of evidence, in particular, application of the exclusionary rule's "good faith" exception, which protects police acting with an objectively "reasonable goodfaith belief" that their conduct is lawful. ${ }^{180}$ Recently, in Davis v. United States, ${ }^{181}$ the Supreme Court held that the exception applies when police comply with settled doctrine, even when the doctrine is later overturned by the Court. ${ }^{182}$ In Davis, Alabama police relied on Eleventh Circuit caselaw based on accepted Supreme Court doctrine affording them a per se right to search the interior of a car incident to the lawful arrest of the driver, ${ }^{183} \mathrm{a}$ position disavowed by the Court after the search of Davis's car. ${ }^{184}$ According to the majority, the officer at the time of the search reasonably relied upon and acted in a manner consistent with Supreme Court (and Eleventh Circuit) doctrine, removing any deterrence function served by the exclusionary rule. ${ }^{185}$

The reliance question, however, is less clear when settled U.S. Supreme Court doctrine is not involved. What should the outcome be when the Court has not definitively spoken on the propriety of particular police conduct, and a state court has approved the conduct while its federal circuit has not (or vice versa), and the Court later condemns the conduct? Presumably, akin to the $\S 1983$ context just discussed, agents acting in a manner consistent with a position adopted by their government's courts would be able to invoke the good faith exception. But if this is so then again the forum-filing decision of prosecutors can drive outcomes. In light of the discord, a preferred outcome, suggested during the Davis oral argument by Justice Sotomayor vis-àvis federal circuit splits, ${ }^{186}$ might be for the doctrinal uncertainty to bar application of the good faith exception. However, at present no such policy prevails, leaving outcomes to again vary with prosecutorial will.

180 See United States v. Leon, 468 U.S. 897, 909 (1984) (quoting Illinois v. Gates, 462 U.S. 213, 255 (1983) (White, J., concurring)).

181131 S. Ct. 2419 (2011).

$182 I d$. at 2429 ("[W] hen binding appellate precedent specifically authorizes a particular police practice, well-trained officers will and should use that tool to fulfill their crimedetection and public-safety responsibilities.").

183 See New York v. Belton, 453 U.S. 454, 461 (1981).

184 See Arizona v. Gant, 556 U.S. 332, 338 (2009).

185 Davis, 131 S. Ct. at 2429.

186 See Transcript of Oral Argument at 33, Davis, 131 S. Ct. 2419 (No. 09-11328), 2011 WL 972573, at *33 ("JUSTICE SOTOMAYOR: Well, if there's a circuit split, how do we encourage police officers to be careful about the Fourth Amendment? . . . . If there's a circuit split and a police officer knows that other circuits are saying this is unconstitutional, why are we taking away the deterrent effect of having thoughts occur to the officer about thinking through whether there's a better way and a legal way to do things?"). 


\section{Obliging the Supreme Court to Be More "Supreme"}

As the preceding discussion makes clear, state-federal conflicts, while an inevitable and indeed beneficial byproduct of the nation's federalist system, create an array of significant problems. The challenge lies in arriving at a solution that accommodates these realities. This Part lays the foundation for the solution proposed in Part IV, by examining reforms proposed to date directed at mediating federal constitutional conflict.

\section{A. Prior Proposals}

Although over the years most concern over constitutional conflict has centered on differences between and among the federal circuits, ${ }^{187}$ state-federal disuniformity has drawn a degree of limited attention. ${ }^{188}$ One proposal, offered by Professor Daniel Meador in the early 1980s, urged creation of a new federal tribunal to review state court decisions concerning federal constitutional questions, ${ }^{189}$ similar to the "national court of appeals" long suggested to resolve federal circuit conflicts. ${ }^{190}$ Professor Meador saw the main advantage of the proposal as being that it would provide a "measure of nationwide uniformity ... . The same tribunal would pass on all federal constitutional questions arising in state criminal proceedings. Thus the law could be kept on an even keel, and its development could be monitored more effectively."191

Allowing direct appeal of state cases to a national intermediate federal tribunal, however, would be problematic for several reasons. Most significant, subjecting state courts to direct oversight by an über lower federal court would signal a troubling institutional distrust of state courts. ${ }^{192}$ More practi-

187 Of the many study groups and commissions over the years, the Hruska Commission and the Federal Courts Study Committee were most prominent. See Comm'n on Revision of the Fed. Court Appellate Sys., Structure and Internal Procedures: Recommendations for Change, reprinted in 67 F.R.D. 195 (1975) [hereinafter Hruska Commission Report]; Judicial Conference of the United States, Report of the Federal Courts Study Committee (1990).

188 See National Advisory Commission on Criminal Justice Standards and Goals, REPORT ON COURTS 129-31 (1973).

189 Daniel J. Meador, Straightening Out Federal Review of State Criminal Cases, 44 Онго Sт. L.J. 273 (1983).

190 See Hruska Commission Report, supra note 187, at 206-07 (voicing concern over "differences in legal rules applied by . . . circuits [that] result in unequal treatment of citizens . . . solely because of differences in geography); $i d$. at 208 (urging "creation of a new national court of appeals, designed to increase the capacity of the . . judicial system for definitive adjudication of issues of national law").

191 Meador, supra note 189, at 280.

192 Indeed, this very concern has driven ongoing efforts to limit federal habeas corpus review of state decisions. See Stone v. Powell, 428 U.S. 465, 491 n.31 (1976) ("Resort to habeas corpus ... results in serious intrusions on values important to our system of government."); Good v. Berghuis, 729 F.3d 636, 639 (6th Cir. 2013) (noting that "traditional federalism and comity principles ... animated Stone v. Powell" and these "considerations ... take center stage whenever evaluating the scope of federal habeas review"). 
cally, the proposal itself, now over thirty years old, has suffered the same lack of success experienced by the national court of appeals vis-à-vis federal circuit splits, quelled by the Supreme Court's estimable ability to neutralize any perceived incursion on its appellate prerogative. ${ }^{193}$ Equally unlikely to succeed for similar institutional reasons, and problematic for similarly succumbing to federal judicial-centrism, is the recent proposal that the Court's merits case logjam be remedied by creation of a new certiorari division, consisting of federal circuit judges, who would select cases for the Court to address. ${ }^{194}$

It has also been suggested that state courts simply defer to lower federal court wisdom, ${ }^{195}$ including that they follow federal positions in "lockstep" fashion, much as they often do in interpreting their own constitutions. ${ }^{196}$ Such proposals, while ensuring uniformity, are deeply problematic because they again undercut state autonomy and ignore the instrumental benefits surveyed above. ${ }^{197}$ They also risk lock-in of unfounded or unwise positions adopted by a majority (or consensus) of lower federal courts, ${ }^{198}$ which could reflect nothing more than a bandwagon effect being at work, ${ }^{199}$ and would have the practical effect of precluding state courts from adopting minority

193 See Thomas E. Baker, A Generation Spent Studying the United States Courts of Appeals: A Chronology, 34 U.C. Davis L. Rev. 395 (2000); David S. Law, How to Rig the Federal Courts, 99 GEO. L.J. 779 (2011).

194 See Paul D. Carrington \& Roger C. Cramton, Judicial Independence in Excess: Reviving the Judicial Duty of the Supreme Court, 94 Cornell L. Rev. 587 (2009).

195 See Matthews, supra note 20, at 83 (urging that state courts defer to federal courts "whenever possible"); Moyer, supra note 126, at 197-98, 206 (calling the federal circuit the "agent" of the Supreme Court and stating that "when a state court fails to follow the decision of a lower federal court that has interpreted the Fourth Amendment, it is implicitly rejecting the determinations of the U.S. Supreme Court as to what constitutes a minimally acceptable floor to effectuate fundamental constitutional rights"); Zeigler, supra note 20, at 1212 ("State courts generally should consider themselves bound by lower federal court decisions when many ... have considered an issue and all have reached the same conclusion.").

196 See M. Jason Hale, Note, Federal Questions, State Courts, and the Lockstep Doctrine, 57 Case W. Res. L. Rev. 927 (2007).

197 See supra Section I.B.

198 See, e.g., State v. Anderson, 136 P.3d 406, 415 (Kan. 2006) (rejecting Tenth Circuit position allowing warrantless arrest of motorist, endorsed by only one other court); see also Rohr Aircraft Corp. v. Cnty. of San Diego, 336 P.2d 521, 524 (Cal. 1959) ("Any rule which would require the state courts to follow in all cases the decisions of one or more lower federal courts would be undesirable, as it would have the effect of binding the state courts where neither the reasoning nor the number of federal cases is found persuasive."); $c f$. Mast, Foos \& Co. v. Stover Mfg. Co., 177 U.S. 485, 488 (1900) ("Comity is not a rule of law .... If it were, the indiscrete action of one court might become a precedent, increasing in weight with each successive adjudication, until the whole country was tied down to an unsound principle.").

199 See Andrew F. Daughety \& Jennifer F. Reinganum, Stampede to Judgment: Persuasive Influence and Herding Behavior by Courts, 1 AM. L. \& ECON. Rev. 158 (1999). 
positions that ultimately get adopted by the Court, such as occurred in Florida v. Jardines, Georgia v. Randolph, and Arizona v. Gant. ${ }^{200}$

Less problematic, Professor Donald Zeigler has argued that state courts should retain some interpretive independence but that they should seek to "decide federal questions the way they believe the Supreme Court would decide them."201 State courts, he maintains, should strive to predict how the U.S. Supreme Court would resolve a federal constitutional or statutory question, serving in effect as the Court's agent. ${ }^{202}$ With the "unifying perspective" afforded, ${ }^{203}$ states will be "more likely to reach consistent results if they ask how the Supreme Court would evaluate conflicting lower court decisions."204

Requiring state courts to decide in line with how they think the Supreme Court would rule is easier said than done, as Professor Zeigler himself acknowledged. ${ }^{205}$ By the Court's own admission, stare decisis is not an "inexorable command" in constitutional matters, ${ }^{206}$ and it is not unusual for the Court to reverse itself when a rule proves "unworkable" 207 or caselaw has "undermined [a precedent's] doctrinal underpinnings."208 Predicting outcomes in constitutional criminal procedure, a doctrinal area more unstable than most, ${ }^{209}$ is especially problematic. ${ }^{210}$

200 See supra notes 98-104 and accompanying text. Florida $v$. J.L. affords another example of a state court bucking the judicial trend and adopting a distinctly minority position later embraced by the Court. See J.L. v. State, 727 So. 2d 204, 212 (Fla. 1998) (Overton, J., dissenting) (noting that the majority's rejection of a "gun exception" for a Terry stop and frisk conflicted with position of every other state and federal court, save the Supreme Court of Pennsylvania), unanimously aff'd sub nom., Florida v. J.L., 529 U.S. 266, 274 (2000).

201 Zeigler, supra note 20, at 1177.

202 Id. at 1184.

203 Id. at 1184-85.

204 Id.; see also id. at 1187-88 ("[T] he goals of correct and uniform interpretation of federal law can best be furthered if state courts decide federal questions the way they think the Supreme Court would decide them.").

$205 I d$. at 1189-1211 (noting, inter alia, the varied interpretive methods of the Justices and the uncertain influence of their political preferences); see also Michael J. Gerhardt, The Power of Precedent 79 (2008) ("[T] he actual process of deciding cases has enough play in the joints to make it difficult, if not impossible, to predict which particular precedents the justices will agree to weaken, if not overrule."); Michael C. Dorf, Prediction and the Rule of Law, 42 UCLA L. REv. 651, 715 (1995). On problems with the principal-agent model of decisionmaking model more generally, see Pauline T. Kim, Beyond Principal-Agent Theories: Law and the Judicial Hierarchy, 105 Nw. U. L. Rev. 535, 561-71 (2011).

206 Payne v. Tennessee, 501 U.S. 808, 828 (1991).

207 See Montejo v. Louisiana, 556 U.S. 778, 792 (2009) ("[T] he fact that a decision has proved 'unworkable' is a traditional ground for overruling it.").

208 Dickerson v. United States, 530 U.S. 428, 430 (2000).

209 See Michael J. Gerhardt, The Irrepressibility of Precedent, 86 N.C. L. REv. 1279, 1282 (2008) (identifying criminal procedure as the area in which the Court has most often reversed its own precedent). For discussion of the Court's tendency to engage in "stealth" and "accidental" overruling of precedent, see Barry Friedman, The Wages of Stealth Overruling (With Particular Attention to Miranda v. Arizona), 99 GEO. L.J. 1 (2010), and Suzanna Sherry, The Four Pillars of Constitutional Doctrine, 32 Cardozo L. Rev. 969 (2011). 
Finally, it has been suggested that state courts be accorded freedom to construe federal constitutional provisions more generously than the Supreme Court, free of its review. Justice John Paul Stevens has been the most visible proponent of this view. ${ }^{211}$ In keeping with the Court's early limited jurisdiction over state court treatment of federal claims, which allowed review only of cases denying claim of a federal right, ${ }^{212}$ Justice Stevens has urged that the Court withhold review when a state court has honored a federal rights claim and the state-government appellant in effect asserts that the court " "overprotected' the citizen." 213 According to Justice Stevens, allowing state courts such latitude would permit federal rights to be tailored "in the light of local conditions," 214 without individual state preferences impacting other states. ${ }^{215}$

Justice Stevens's position has been advocated by and elaborated upon by others, ${ }^{216}$ and while it has considerable appeal, ${ }^{217}$ it elides the serious difficulties associated with intrastate disuniformity. Even if Justice Stevens is correct that the impact of granting a more expansive right is not externalized to other jurisdictions, ${ }^{218}$ the problem remains that negative effects will be inter-

210 See, e.g., State v. Baldon, 829 N.W.2d 785, 826 (Iowa 2013) (Appel, J., concurring) (" $[\mathrm{P}]$ ast cases demonstrate that it is difficult to determine the methodology that the United States Supreme Court will apply to determine a search and seizure issue. In recent years, the Supreme Court has applied at least five different analytical models . . . . [I]t is impossible to predict which model will apply."). On the instability of Fourth Amendment doctrine more generally, see Thomas Y. Davies, The Supreme Court Giveth and the Supreme Court Taketh Away: The Century of Fourth Amendment "Search and Seizure" Doctrine, 100 J. CRIM. L. \& CRIMINOLOGY 933 (2010).

211 See, e.g., Kansas v. Marsh, 548 U.S. 163, 200 (2006) (Stevens, J., dissenting); Delaware v. Van Arsdall, 475 U.S. 673, 695 (1986) (Stevens, J., dissenting); California v. Carney, 471 U.S. 386, 396-98 (1985) (Stevens, J., dissenting); Michigan v. Long, 463 U.S. 1032, 1067-70 (1983) (Stevens, J., dissenting); California v. Ramos, 463 U.S. 992, 1031 (1983) (Stevens, J., dissenting).

212 See supra note 52 and accompanying text.

213 Long, 463 U.S. at 1068 (Stevens, J., dissenting).

214 Ponte v. Real, 471 U.S. 491, 502 (1985) (Stevens, J., concurring in part).

215 See Marsh, 548 U.S. at 201 (Stevens, J., dissenting) ("[N]o other state would have been required to follow the [Kansas] precedent if it had been permitted to stand."); Brigham City v. Stuart, 547 U.S. 398, 409 (2006) (Stevens, J., concurring) ("Federal interests are not offended when a single State elects to provide greater protection for its citizens than the Federal Constitution requires.").

216 See Thomas H. Lee, Countermajoritarian Federalism, 74 Fordham L. Rev. 2123, 2132 (2006); Mazzone, supra note 19, at 73; Sager, supra note 92, at 1249.

217 Not by the lights of Justice Scalia, it is worth noting, who condemned "[t] urning a blind eye to federal constitutional error that benefits criminal defendants." Marsh, 548 U.S. at 185 (Scalia, J., concurring); cf. Erwin Chemerinsky, Parity Reconsidered: Defining a Role for the Federal Judiciary, 36 UCLA L. REv. 233, 258 (1988) (asserting that it is "wrong to presuppose that decisions in favor of [individual civil liberties] are preferable" to decisions favoring "government interests").

218 See supra note 215 and accompanying text; see also Richard A. Posner, The Federal CourTs 280-92 (1996) (arguing that disuniformity is unproblematic so long as a state court decision does not externalize costs to other states and their citizens). 
nalized in individual states, as the variable doctrinal positions play out on the streets and in state and federal courthouses.

\section{B. The Imperative of Supreme Court Intervention}

By design, the conflicts surveyed here can only be resolved by the nation's "one supreme Court." 219 It alone is "supreme in the exposition of the law of the Constitution," 220 and is empowered to resolve constitutional uncertainty ${ }^{221}$ and ensure uniformity. ${ }^{222}$ State and lower federal courts alike recognize the Court's singular role in this regard and expect the Court to fulfill its duty. ${ }^{223}$

In theory, the Court does so by exercise of its discretionary certiorari authority. Since first being afforded by Congress in the late nineteenth century, and augmented since, the Court's certiorari power has been marked by a quid pro quo: that, in return for being relieved of its historically heavy

\section{U.S. Const. art. III, § 1.}

220 United States v. Morrison, 529 U.S. 598, 616 n.7 (2000) (internal quotation omitted); see also Henry Paul Monaghan, On Avoiding Avoidance, Agenda Control, and Related Matters, 112 Colum. L. Rev. 665, 681 n.79 (2012) (referring to the Supreme Court as "the priestly interpreter of our Constitution"); Ratner, supra note 52, at 160-61 ("[The] $[\mathrm{C}]$ ourt alone is expressly given appellate jurisdiction over cases involving the supreme law of the land whether those cases are initiated in state or federal court. [The Court] is thus the constitutional instrument for implementing the [S] upremacy [C]lause.").

221 See Dodge v. Woolsey, 59 U.S. (18 How.) 331, 350 (1855) ("[The nation] would be incomplete and altogether insufficient for the great ends contemplated, unless a constitutional arbiter was provided to give certainty and uniformity, in all of the States, to the interpretation of the constitution and the legislation of congress ...."); Cohens v. Virginia, 19 U.S. (6 Wheat.) 264, 415-16 (1821) ("[N]othing but contradiction and confusion can proceed .... [without] vesting in some single tribunal the power of deciding, in the last resort, all cases in which [the Constitution and federal laws] are involved.").

222 See Erwin Chemerinsky, Federal Jurisdiction $\$ 10.1$, at 638-39 (4th ed. 2003) (stating that the Court's power to review state and lower federal court opinions "serves to ensure the uniformity of federal law," allowing "federal law [to] mean the same thing in all parts of the country"); Larry Alexander \& Frederick Schauer, On Extrajudicial Constitutional Interpretation, 110 HaRv. L. Rev. 1359, 1379, 1385 (1997) (emphasizing Court's role "as the authoritative settler of constitutional meaning" and warning of "interpretive anarchy" in its absence); see also Fed. Judicial Ctr., Report of the Study Group on the Caseload of the Supreme Court (1972), reprinted in 57 F.R.D. 573, 578 (1973) (describing the core roles of the Court as being "to define and vindicate . . rights guaranteed by the Constitution, to assure the uniformity of federal law, and to maintain the constitutional distribution of powers in a federal union").

223 As the Florida Court of Appeals put it:

In a system where the decisions of lower federal courts in Florida are not binding on the state courts, there may very well be occasions when the federal courts hold one way, while the state courts hold the contrary. That is after all a consequence of our system of dual sovereignty. The remedy is simple: the United States Supreme Court can eliminate the conflict by simply taking up an appropriate case for review.

Kidwell v. State, 696 So. 2d 399, 405 (Fla. Dist. Ct. App. 1997). 
mandatory appellate caseload, ${ }^{224}$ the Court would use its power to settle constitutional conflicts. ${ }^{225}$ The expectation is evidenced in the modern Court's own rules, which specify that a conflict qualifies as a "compelling reason[ ]" to grant certiorari. ${ }^{226}$

As noted earlier, however, certiorari has not been up to the task. ${ }^{227}$ Even if at one time the Court could be expected to resolve constitutional conflict via certiorari, ${ }^{228}$ today multiple intrastate conflicts exist. ${ }^{229}$ And the Court, despite on occasion expressing awareness of state-federal constitutional conflict more generally, ${ }^{230}$ and professing stalwart dedication to its settlement role, ${ }^{231}$ ignores pleas for it to intervene. ${ }^{232}$

224 See Tara Leigh Grove, The Exceptions Clause as a Structural Safeguard, 113 Colum. L. REv. 929, 945-46, 963-68 (2013).

225 Id.; see also Edward A. Hartnett, Questioning Certiorari: Some Reflections Seventy-Five Years After the Judges' Bill, 100 Colum. L. Rev. 1643, 1685, 1705 (2000) (noting Justices' assurance to Congress, when contemplating passage of the "Judges' Bill" of 1925, "that certiorari is always granted when there is a conflict between courts of appeals and would always be granted when there was an arguable constitutional claim"). On the Court's evolution from a mainly mandatory to an almost exclusively discretionary, certiorari-based docket, see Kathryn A. Watts, Constraining Certiorari Using Administrative Law Principles, 160 U. PA. L. Rev. 1, 7-18 (2011).

226 Sup. Cт. R. 10(a)-(b).

227 See supra notes $36-38$ and accompanying text.

228 See, e.g., Frankfurter, supra note 1, at 517 (confidently stating that " $[\mathrm{t}]$ he national interest in the uniform interpretation of . . . federal law is amply protected by the reviewing power of the Supreme Court through certiorari."); see also Procedure in Federal Courts: Hearing on S.2060 and S.2061 Before the Subcomm. on the Judiciary, 68th Cong. 29-30 (1924) (statement of Justice William Van Devanter) ("Whenever we find . . . a conflict [among the state supreme courts or circuit courts of appeals] that, without more, leads to the granting of the petition ... ."); Authority in State Courts, supra note 20, at 948 ("Whichever forum, state or federal, is chosen, the same opportunity for ultimate resolution by the Supreme Court is available. The uniformity thus assured prevents advantage from being taken of temporary disharmony between state and lower federal court decisions.").

229 See supra notes 133-56 and accompanying text.

230 See, e.g., Brigham City v. Stuart, 547 U.S. 398, 402 (2006) (noting that certiorari was granted "in light of differences among state courts and the Courts of Appeals").

231 See, e.g., Justices in Their Own Words: Granting Certiorari, supra note 37 ("Our main job is to try to make sure [that] federal law is uniform across the country.") (quoting Chief Justice John Roberts)).

232 See supra note 234 and accompanying text. Although beyond the scope of study here, it bears mention that conflicts also arise regarding the constitutionality of state substantive law, and can endure for decades in the absence of Supreme Court intervention. One such example concerns Florida's disorderly conduct statute, which a federal district court found unconstitutionally vague in 1970, expressing the "hope" that Florida state courts would agree. Severson v. Duff, 322 F. Supp. 4, 10 (M.D. Fla. 1970). The hope went unfulfilled, with Florida courts upholding the law as recently as 1996, despite an intervening finding by the Fifth Circuit that the law was unconstitutional. See DeWald v. Wyner, 674 So. 2d 836, 838 (Fla. Dist. Ct. App. 1996) (citing with disapproval Wiegand v. Seaver, 504 F.2d 303, 306 (5th Cir. 1974)). 
It is hard to say why this is so, given the Court's famously inscrutable certiorari decision-making process. ${ }^{233}$ Perhaps the Justices are comforted by the expectation that conflicts, if worthy of certiorari, will come before them again:234 or that they will in time resolve themselves on their own through the common law process. ${ }^{235}$ Even if correct, however, such self-assurance gives short shrift to the real-world negative consequences of the discord, noted earlier, accruing in the interim. ${ }^{236}$

From an institutional perspective, the Court's failure is troubling enough; yet it becomes more so in light of the fact that constitutional settlement cannot be achieved by other means. Without Supreme Court review, as then-Professor Ruth Ginsburg noted, a state court can effectively immunize its decision because "[t]he state court's federal law determination [cannot] be overturned" by the state electorate or legislature. ${ }^{237}$ At the same time, federal constitutional amendment-through Article $\mathrm{V}^{238}$ - holds no more promise. Although it is conceivable that a decision or series of decisions from the Court could generate discord sufficient to trigger the amendment process, it is highly unlikely that an unpopular state court decision would do so, if for no other reason than that its effects would be cabined to a single state. ${ }^{239}$

As a consequence, in the absence of Supreme Court intervention, state and lower federal courts enjoy plenary power over federal constitutional law in their respective spheres, ${ }^{240}$ without any felt obligation to coordinate or

233 See Watts, supra note 225, at 14-21 (discussing transparency concerns).

234 In one of the standard treatments of the Court's agenda-setting dynamic, for instance, William Perry relates how justices and their clerks see cases in terms of their "fungibility": that the issue raised in a petition will resurface in the petition pool. H.W. Perry, Jr., Deciding to Decide 221 (1991). According to one clerk: "[The issue is] going to come up again if it's really an important issue. . . . I can say I never really feared that if we don't take it now or miss this one, that we won't have the chance to decide it again." Id.

235 See, e.g., Ruth Bader Ginsburg, Workways of the Supreme Court, 25 T. Jefrerson L. Rev. 517,521 (2003) (noting that the Court does not focus on splits "likely to heal").

236 See United States v. Johnson, 457 U.S. 537, 560 (1982) (" [Y] ears may pass before the Court finally invalidates a police practice of dubious constitutionality.").

237 Ruth Bader Ginsburg, Book Review, 92 Harv. L. Rev. 340, 343-44 (1978) (reviewing Laurence H. Tribe, American Constitutional Law (1978)).

238 U.S. Const. art. V.

239 See Mazzone, supra note 49, at 1050-51; see also id. ("While multiple state courts ruling in a highly unpopular way on a constitutional issue might provoke an amendment, such instances are likely to be very rare."). State court conflict with circuit norms could conceivably be avoided by a state constitutional amendment. Florida, for instance, in the 1980s amended its state constitution to reflect that search and seizure doctrine will conform to the opinions of the U.S. Supreme Court. See Smallwood v. State, 113 So. 3d 724, 730 (Fla. 2013) (citing and discussing FlA. Const. art. I, § 12). An analogous provision conceivably could be adopted to tie state court interpretation of the federal constitution to Eleventh Circuit precedent.

240 See Frank B. Cross, Decision Making in the U.S. Courts of Appeals 2 (2007) (noting that the Court's shrunken docket results in federal circuits typically having final say over federal law); Pfander, supra note 42, at 233 ("With the Court granting review in fewer than eighty cases a year, and with only a relatively modest number of those cases coming 
standardize rules. ${ }^{241}$ Worse yet, the conflicts go unmediated by federal habeas corpus review, which for many years allowed federal court oversight of state decisions, ${ }^{242}$ but today, after major limits being imposed by the Court $^{243}$ and Congress, ${ }^{244}$ no longer meaningfully figures in the state-federal decisional dynamic. ${ }^{245}$

\section{A Proposed Solution}

In the absence of an effective and reliable certiorari regime, something is needed to oblige the Supreme Court to resolve the conflicts surveyed here, constituting what Justice Joseph Story referred to as the "jarring and discor-

from the state courts, state courts now exercise final authority in virtually every federal question case that comes before them.").

241 In this sense, they function in a manner akin to stand-alone industries in the national marketplace, which are inured to "network effects" that pressure businesses to standardize and conform to market norms. See Michael L. Katz \& Carl Shapiro, Systems Competition and Network Effects, 8 J. Econ. Persp. 93, 105 (1994) ("In markets with network effects, there is [a] natural tendency toward de facto standardization, which means everyone [is] using the same system.”). On network effects more generally, see Mark A. Lemley \& David McGowan, Legal Implications of Network Economic Effects, 86 Calif. L. Rev. 479 (1998).

242 See, e.g., Conner v. State, 303 S.E.2d 266, 273 (Ga. 1983) (“[W]e are not bound by decisions of the lower federal courts. Nonetheless, it would be . . myopic of us to ignore federal precedent, if only because of the inevitability of federal collateral review . . .."); Commonwealth v. Negri, 213 A.2d 670, 672 (Pa. 1965) ("If the Pennsylvania courts refuse to abide by [the Third Circuit's] conclusions, then the individual to whom we deny relief need only to 'walk across the street' to gain a different result. Such an unfortunate situation would cause disrespect for the law.").

243 See Stone v. Powell, 428 U.S. 465, 494 (1976) (holding that state court Fourth Amendment decisions are to be reviewed only if a petitioner lacked a "full" and "fair" opportunity to litigate the issue in state court); see also J. Thomas Sullivan, Danforth, Retroactivity, and Federalism, 61 Окца. L. Rev. 425, 467 (2008) ("[Stone] effectively insulated the bulk of state court determinations from review in the federal system except by petition for writ of certiorari to the Supreme Court itself.").

244 See Anti-Terrorism and Effective Death Penalty Act of 1996 (AEDPA), Pub. L. No. 104-132, 110 Stat. 1214 (codified at 28 U.S.C. $\$ \$ 2241-2254$ (2012)). As a result of the AEDPA, a federal court is to assess only whether a state decision is "contrary to, or involved an unreasonable application of, clearly established Federal law, as determined by the Supreme Court of the United States," or was based on an "unreasonable determination of the facts." 28 U.S.C. $\$ 2254(\mathrm{~d})(1)(2)$. The Court has "emphasized, time and again, that [the AEDPA] prohibits the federal courts of appeal from relying on their own precedent to conclude that a particular constitutional principle is 'clearly established.' " Lopez v. Smith, No. 13-946, 2014 WL 4956764, at*1 (U.S. Oct. 6, 2014) (per curiam).

245 A state court decision, the Supreme Court has instructed, is to be invalidated only if it is "so lacking in justification that there was an error well understood and comprehended in existing law beyond any possibility for fairminded disagreement." Harrington v. Richter, 131 S. Ct. 770, 786-87 (2011); see also Giovanna Shay \& Christopher Lasch, Initiating a New Constitutional Dialogue: The Increased Importance Under AEDPA of Seeking Certiorari from Judgments of State Courts, 50 WM. \& Mary L. REv. 211 (2008) (discussing the vastly diminished capacity of federal habeas review). 
dant judgments" that only the Court can "harmonize . . . into uniformity."246 The prospect for change, it should be noted at the outset, is not likely to be forthcoming from the Court itself, which reflexively resists any effort seen as limiting its docket-selection prerogative. ${ }^{247}$

Yet an option remains that can compel the Court's intervention: certification. Since 1802, certification has allowed disputed questions of federal law, generated by lower federal courts, to get to the Supreme Court for resolution. ${ }^{248}$ Absent certification, Chief Justice Marshall wrote in 1821, a "division of opinion" might "remain[] and the question would continue unsettled."249

Certification was widely used in nineteenth-century criminal cases ${ }^{250}$ and it later figured centrally in congressional creation of the several federal circuit courts of appeal to "guard against diversity of judgment in . . . different courts." 251 Technically a vestige of the Court's mandatory appellate jurisdiction, ${ }^{252}$ the availability of certification allayed congressional concern that the Court would falter in its settlement role after it was afforded essentially plenary certiorari discretion in $1925 .{ }^{253}$ Notwithstanding this pedigree, and

246 Martin v. Hunter's Lessee, 14 U.S. (1 Wheat.) 304, 348 (1816).

247 See Monaghan, supra note 220, at 679 ("The Court seeks as much freedom as possible over what is to be finally and authoritatively decided."); Owens \& Simon, supra note 36 , at 1283 (noting that unless the Court becomes more ideologically homogenous or includes Justices determined to resolve conflicts that "the Court will continue to decide a small number of cases per Term").

248 Act of Apr. 29, 1802, ch. 31, § 6, 2 Stat. 156, 159.

249 United States v. Daniel, 19 U.S. (6 Wheat.) 542, 548 (1821) (Marshall, C.J.).

250 See Ratner, supra note 52, at 196 (noting the same and citing cases). Indeed, it was long the case that certification was the only way that a criminal matter could reach the Supreme Court. See United States v. Rider, 163 U.S. 132, 138 (1896) (noting that with criminal cases "a certificate of division was the only mode in which alleged errors could be reviewed").

251 See 21 Cong. Rec. 10,222 (1890) (statement of bill sponsor Sen. William Evarts).

252 See 17 Charles Alan Wright et al., Federal Practice and Procedure $\$ 4038$, at 62 (3d ed. 2007) ("In form and history . . certified question jurisdiction is mandatory."); Felix Frankfurter \& James M. Landis, The Business of the Supreme Court at October Term, 1929, 44 Harv. L. Rev. 1, 35 (1930) ("Petitions for certiorari the Court can deny, but questions certified must be answered.").

253 See Hartnett, supra note 225, at 1656 ("[C] ertiorari was envisioned as a sort of fallback provision should the circuit courts of appeals prove, on occasion, to be surprisingly careless in deciding cases or issuing certificates."). 
the fact that certification remains a part of the U.S. Code, ${ }^{254}$ it has been used only infrequently since 1940 (and not at all since 1981). ${ }^{255}$

Joining a handful of other scholars suggesting resuscitation of certification more generally, ${ }^{256}$ I recently urged elsewhere that the certification statute be retooled by Congress to require that the Court accept a certified question of constitutional law on which two or more federal circuit courts have split. ${ }^{257}$ Certification is equally suited to resolve intra-circuit, state-federal conflicts yet Congress has never even nominally made the instrument available to state courts. ${ }^{258}$

Although the reason for the absence of a state certification mechanism cannot be identified with certainty, ${ }^{259}$ the omission is in keeping with the common yet mistaken sensibility that federal courts are the sole source of federal constitutional common law (and hence potential conflict). The time is long past due for Congress to expand certification and give effect to the significant federal constitutional role that state courts have come to play. ${ }^{260}$ In so doing, Congress, which itself has a strong institutional interest in promoting and ensuring the Court's settlement role, ${ }^{261}$ would act in a manner in keeping with the originating purpose of certification: to resolve intra-juris-

254 See 28 U.S.C. § 1254(2) (2012) (providing for Court review "[b]y certification at any time by a court of appeals of any question of law in any civil or criminal case as to which instructions are desired, and upon such certification the Supreme Court may give binding instructions or require the entire record to be sent up for decision of the entire matter in controversy"). Certification is also provided for in the Court's rules. See Sup. Cт. R. 19(1) ("A United States court of appeals may certify to [the] Court a question or proposition of law on which it seeks instruction for the proper decision of a case.").

255 See United States v. Seale, 558 U.S. 985, 986 (2009) (Stevens, J., dissenting from dismissal of certified question).

256 See, e.g., Kent S. Bernard, Certified Questions in the Supreme Court: In Defense of an Option, 83 Dick. L. Rev. 31 (1978); Tracey E. George \& Chris Guthrie, Remaking the United States Supreme Court in the Courts' of Appeals Image, 58 Duke L.J. 1439, 1449-51 (2009); Aaron Nielson, The Death of the Supreme Court's Certified Question Jurisdiction, 59 Cath. U. L. Rev. 483, 491-92 (2010).

257 See Logan, supra note 9, at 1188-89.

258 See William Howard Taft, The Jurisdiction of the Supreme Court Under the Act of February 13, 1925, 35 YALE L.J. 1, 5 (1925) ("There is no review provided for by certification of questions by the judges of the state court to the Supreme Court.").

259 The omission might to some extent be explained by the fact that at the time of Barron v. Baltimore (1833), and in 1802 when certification originated, state courts lacked an explicit role vis-à-vis federal constitutional interpretation. However, the certification statute has been reconsidered on numerous occasions since then and was expanded in 1925 to allow the Federal Court of Claims certification authority. See James Moore \& Alan Vestal, Present and Potential Role of Certification in Federal Appellate Procedure, 35 VA. L. REv. 1, 17-19 (1949) (citing 28 U.S.C. § 1255, repealed by Pub. L. 97-164, § 123, 96 Stat. 36 (1982)).

260 An evolution manifested, for instance, in the decision by Congress in 1914 to grant the Court discretionary certiorari power beyond state cases denying a federal right to include cases granting a federal right. See supra notes 53-54 and accompanying text.

261 See Grove, supra note 224, at 944-46 (surveying interest from the late nineteenth century onward among members of Congress, from across the political spectrum, in the institutional role of the Court as the arbiter of constitutional conflict). 
dictional conflicts (stemming from deadlocked two-judge circuit panels in existence early in the nation's history). ${ }^{262}$

Mindful of the political and institutional ramifications of adding to the Court's mandatory jurisdiction, however, the expansion in certification should extend to only intrastate, state-federal circuit court conflicts. ${ }^{263}$ Although conflicts between other courts-state courts with one another and a state court with a federal circuit in another region-are problematic in principle, they do not present the many serious practical difficulties of intrastate, state-federal conflicts noted above. ${ }^{264}$

The mechanics of the amended certification provision could largely track those of the current regime. As now required, consistent with congressional authority to "regulat[e]" the Court's appellate jurisdiction ${ }^{265}$ and the Court's limited original jurisdiction, ${ }^{266}$ the question of law certified should be distinct and definite and be accompanied by a statement of undisputed facts. ${ }^{267}$ Also, as is currently the case, the Court would enjoy authority to dismiss a certified question due to failure to follow the aforementioned

262 See Moore \& Vestal, supra note 259, at 12.

263 This is so even though the expansion in mandatory jurisdiction concerns construction of the U.S. Constitution, a task historically viewed as warranting such jurisdiction. See William Howard Taft, The Attacks on the Courts and Legal Procedure, 5 Ky. L.J. 3,18 (1916) ("The only jurisdiction that [the Supreme Court] should be obliged to exercise ... should [relate to] questions of constitutional construction."). Historically, it is worth noting, the scope of the Court's mandatory jurisdiction was seen as inconsistent with its settlement function, with the crush of cases denying it opportunity to resolve conflict. See Grove, supra note 224 , at 971,996 . The expansion proposed here is designed to serve that very function.

264 As a matter of course, conflicts should concern disputes between state supreme courts and federal circuit courts of appeal. Conflicting decisions of state intermediate courts of appeal could prove ephemeral, being resolved by a state supreme court, or warrant less concern because of their limited jurisdictional reach (say a region of a state, as with Florida's system). Exceptions might be made for when a state supreme court has denied review or when a state has a "unified" appellate system, where the decision of an intermediate court affects an entire state. In such a circumstance, a state supreme court or intermediate appellate court should enjoy certification authority.

265 U.S. Const. art. III, § 2, cl. 2; see also Moore \& Vestal, supra note 259, at 34-35 (" $[\mathrm{W}]$ here the certificate meets the established standards as to operative facts and distinct and definite questions of law the Supreme Court's appellate jurisdiction is invoked, and no valid objection can . . . be based upon the decisive character of the certified questions .....").

266 See Wheeler Lumber Bridge \& Supply Co. v. United States, 281 U.S. 572, 577 (1930) (noting that the Court only resolves certifications involving "distinct questions of law and not of the whole case, for otherwise it would be assuming original jurisdiction withheld from [the Court] by the Constitution").

267 Wright \& Kane, supra note $68, \S 106$, at 779. According to Supreme Court Rule 19, " $[t]$ he certificate shall contain a statement of the nature of the case and the facts on which the question or proposition of law arises. Only questions or propositions of law may be certified, and they shall be stated separately and with precision." Sup. Cт. R. 19(1). 
requirements, ${ }^{268}$ either on its own initiative or as a result of argument of the parties. $^{269}$

Current law on when a question can be certified, however, would benefit from modification. The certification statute at present provides that a court can seek to have a question certified "at any time." 270 Adding a requirement that a state or federal circuit court actually resolve a question in a conflicting matter would reserve the Court's resources for conflicts that actually come to fruition and create the concrete harms surveyed above. Requiring an actual decision, moreover, would provide the Court with the benefit of the reasoning of lower courts, should it wish to avail itself of that reasoning.

Such a change would have several significant benefits. First and foremost, it would allow for the accelerated, authoritative resolution of conflicts, ${ }^{271}$ which, while a natural and even beneficial part of the nation's constitutional structure, create an array of difficulties. ${ }^{272}$ It would also promote judicial efficiency, ${ }^{273}$ as it is not unusual for the same doctrinal dispute to arise and exist not only in several states within a given circuit, ${ }^{274}$ but also in other circuits. ${ }^{275}$

Second, the expansion would afford state and lower federal courts alike a means to participate in the Court's docket-assemblage process, again con-

268 See, e.g., Adams, Cunningham \& Co. v. Jones, 37 U.S. (12 Pet.) 207, 213 (1838) (" $[\mathrm{T}] \mathrm{o}$ express an opinion upon the whole facts of the case, instead of particular points of law growing out of the same[,] [is] a practice which is not deemed by the majority of the Court to be correct, under the act of Congress on this subject."). An exception might also exist when the question certified is already subject to resolution as a result of certiorari. See United States v. Penaranda, 543 U.S. 1117 (2005). In any such instance the Court should specify why the certified questioned was dismissed. Cf. Watts, supra note 225 , at $46-47$ (urging that transparency interests oblige that the Court provide reasons for denials of certiorari).

269 See Moore \& Vestal, supra note 259, at 37 ("A party may move the Court to dismiss the certificate as improper. The parties are entitled to argue the certified questions; and on their failure to do so the Court may dismiss the certification for want of prosecution." (footnote omitted)).

270 See 28 U.S.C. $\$ 1254$ (2) (2012) (allowing "certification at any time by a court of appeals of any question of law in any civil or criminal case as to which instructions are desired, and upon such certification the Supreme Court may give binding instructions or require the entire record to be sent up for decision of the entire matter in controversy.").

271 See Chi., Burlington \& Quincy Ry. Co. v. Williams, 214 U.S. 492, 495-96 (1909) (Holmes, J., dissenting) ("[Certified] questions are to be encouraged as a mode of disposing of cases in the least cumbersome and most expeditious way.").

272 See supra Sections I.B, II.B.

273 Cf. Roger J. Miner, Federal Court Reform Should Start at the Top, 77 Judicature 104, 106-107 (1993) ("Where the Supreme Court has not spoken on an issue, but some circuits have resolved the question in one way and some in another, litigation is encouraged in those circuits that have not yet spoken."); id. at 107 ("Aside from the fact that fairness is lost and justice is not seen to be done, the lower courts become clogged with cases that would not be brought if the law was clearly stated.").

274 See supra note 164 and accompanying text.

275 See, e.g, supra notes 146, 151 and accompanying text. 
sistent with a main originating purpose of certification. ${ }^{276}$ Courts, not litigants, would "distinguish a small handful of cases from the flood of frequently worthless certiorari petitions that engulf the Court," 277 which themselves regularly fail to highlight intrastate conflict. ${ }^{278}$ Doing so would also loosen the grip of the powerful Supreme Court Bar, which has come under criticism for its undue influence over the Court's merits docket. ${ }^{279}$ Equally if not more important, the expansion would facilitate greater engagement by the Court in the refinement of its criminal procedure doctrine, ${ }^{280}$ especially as it involves state courts, ${ }^{281}$ whose decisions today account for only a negligible part of the Court's docket ${ }^{282}$ - a diminished number that has disproportionately contributed to the massive decrease in the Court's overall docket size in recent years. ${ }^{283}$

Despite the foregoing benefits, the changes proposed will likely generate opposition. Those revering Bickelian "passive virtues" and judicial restraint more generally, ${ }^{284}$ for instance, will not rush to embrace a more ambitious

276 Hartnett, supra note 225, at 1710 ("In the hearings on the [1925 Judges Act], it was repeatedly noted that the Supreme Court would not alone control its jurisdiction, but that the courts of appeals, by use of certification, would share in that control.").

277 Wright ET AL., supra note 252, § 4038, at $65 \&$ n.14.

278 See, e.g., Petition for Writ of Certiorari at 7-8, Georgia v. Randolph, 547 U.S. 103 (2006) (No. 04-1067), 2005 WL 309364, at *5 (merely citing contrary Eleventh Circuit position in lengthy string cite of multiple state and federal circuit court cases).

279 See, e.g., Richard J. Lazarus, Docket Capture at the Supreme Court, 119 Yale L.J. OnLine 89, 89-90 (2009) (noting the influence of "an elite group of expert Supreme Court advocates," and criticizing its "undesirable skewing in the content of the Court's docket"); Watts, supra note 225, at 62-63 (discussing role of influential "expert Supreme Court bar" and the capture risks that it creates).

280 See Arthur D. Hellman, The Shrunken Docket of the Rehnquist Court, 1996 Sup. Cт. Rev. 403, 436-37 (condemning the tendency of the Court to "remain[ ] aloof from the day-today operation of the rules it lays down"); $c f$. Frederick Schauer, Abandoning the Guidance Function: Morse v. Frederick, 2007 Sup. Cт. REv. 205, 206-07 (critiquing the Court for its failure to address questions left unresolved in its decisions).

281 See Benesh \& Martinek, supra note 75, at 817 (urging that the Court "tak[e] more than a handful of cases from the state courts, thereby providing more guidance to the lower courts and ensuring greater uniformity"); Martin H. Redish, Supreme Court Review of State Court "Federal" Decisions: A Study in Interactive Federalism, 19 GA. L. REv. 861, 865 (1985) (advocating increased review of state decisions to foster federal-state dialogue on federal questions).

282 See The Supreme Court 2011 Term: The Statistics, 126 Harv. L. REv. 388, 397, 403 (2012) (noting that in the 2011 Term only 6 of 179 cases (including full opinions and memorandum orders), or $0.03 \%$, of cases disposed of, originated in state courts).

283 Michael E. Solimine, Supreme Court Monitoring of State Courts in the Twenty-First Century, 35 Ind. L. Rev. 335, 352 (2002) (stating that the Court's diminished docket size was "significantly and . . . disproportionately" driven by the "sharp decline of state court cases reviewed"). Professor Solimine notes that in the four decades leading up to the 1990s the Court reviewed on average thirty-seven state court cases per term, roughly $25 \%$ of the cases decided in a term, and that the percentage of state cases decreased from $30 \%$ in 1989 to $16 \%$ in 1999. Id. at 353 tbl.1.

284 See Alexander M. Bickel, Foreword: The Passive Virtues, 75 Harv. L. Rev. 40 (1961). 
constitutional settlement role from the Court. Indeed, to some the Court's lack of involvement is actually a good thing, allowing constitutional matters to "percolate" until such time as the Court sees fit to intervene. ${ }^{285}$

Percolation, however, remains highly contestable, despite occasional mention by the Court of its virtues. ${ }^{286}$ As Chief Justice Rehnquist noted over twenty-five years ago:

$[\mathrm{T}] \mathrm{o}$. . . suggest that it is actually desirable to allow important questions of federal law to "percolate" in the lower courts for a few years before the Supreme Court takes them on seems to me a very strange suggestion .... ... We are not engaged in a scientific experiment or in an effort to square the circle . . . . [T] here is no obviously "correct" . . answer in the philosophical or mathematical sense, but the "definitive" answer, and the definitive answer can be given ... only by the court of last resort. It is of little solace to the litigant who lost years ago in a court of appeals decision to learn that his case was part of the "percolation" process which ultimately allowed the Supreme Court to vindicate his position. ${ }^{287}$

Nor is percolation evidenced much in the actual workings of the Supreme Court, based on the survey undertaken here of Roberts Court criminal procedure decisions. Only in a single instance did the Court forthrightly articulate and contextualize doctrinal variation among state and lower federal courts on a question. ${ }^{288}$ Although the absence of overt critical examination of the merits of doctrinal positions of course does not conclusively disprove operation of percolation, ${ }^{289}$ the failure to articulate intellectual

285 See, e.g., Samuel Estreicher \& John Sexton, Redefining the Supreme Court's Role 48 (1986) ("The Supreme Court, when it decides a fully percolated issue . . . has the benefit of the experience of . . . lower courts, often yielding concrete information about how a particular rule will 'write,' its capacity for dealing with varying fact patterns, and the merits of alternative approaches."); Charles L. Black, Jr., The National Court of Appeals: An Unwise Proposal, 83 YALE L.J. 883, 898 (1974) ("[Conflicts] can be endured and sometimes ... ought to be endured while judges and scholars observe the respective workings out in practice of the conflicting rules ....").

286 See, e.g., California v. Carney, 471 U.S. 386, 399 (1985) (Stevens, J., dissenting) (condemning "[p]remature resolution of the novel [Fourth Amendment] question presented [that] has stunted the natural growth and refinement of alternative principles"); E.I. du Pont de Nemours \& Co. v. Train, 430 U.S. 112, 135 n.26 (1977) (noting the "wisdom of allowing difficult issues to mature through full consideration" by the lower courts).

287 William H. Rehnquist, The Changing Role of the Supreme Court, 14 FLA. ST. U. L. REv. 1, 11 (1986); see also Thomas E. Baker \& Douglas D. McFarland, The Need for a New National Court, 100 Harv. L. Rev. 1400, 1408 (1987) ("We cannot accept the underlying logic behind percolation-the notion that somehow a better reasoned Supreme Court decision will result from subjecting citizens in different parts of the country to differing interpretations of the same national law ....").

288 See Kentucky v. King, 131 S. Ct. 1849, 1858-61 (2011) (methodically surveying state and federal court positions adopted on the "police-created" exigency doctrine). Professor Bruhl recently examined the Court's invocation of lower court splits more generally, covering the period October 2010 through June 2013, and similarly concluded that "[1] owercourt precedent enjoys at most modest influence on the Supreme Court." Aaron-Andrew P. Bruhl, Following Lower-Court Precedent, 81 U. CHI. L. Rev. 851, 922 (2014).

289 Logan, supra note 9, at 1169. 
underpinnings of competing decisions, at a minimum, undermines the posited informed deliberateness of percolation and justifies skepticism over its place in constitutional decisionmaking. ${ }^{290}$ In any event, whatever advantages that might accrue from percolation are substantially outweighed by the very substantial costs of disuniformity. ${ }^{291}$ As noted by Justice Brandeis, "it is more important that the applicable rule of law be settled than that it be settled right." 292

A more valid potential concern lies in whether a state or federal court, upon adopting a variant position, might lack incentive to certify. In Arizona v. Gant, for instance, the Arizona Supreme Court, preferring the discordant position it adopted limiting police authority to search a car incident to arrest, could well have been content to not run the risk of having itself reversed and lose at least the state-bounded effect of its decision. Given this possibility, Congress should empower federal circuit courts with certification power in the event of a conflict with state courts within their territory. To further limit the risk of avoidance, consideration should be given to allowing the Office of the Solicitor General, an institutional actor charged with being a superintendent of national law, ${ }^{293}$ to seek clarification by means of certification. ${ }^{294}$

Ultimately, the risk of avoidance would hopefully be mitigated by awareness of the practical problems, highlighted here, resulting from conflict. It also can be hoped that a second-in-time deciding court will have an incentive

290 See, e.g., Caminker, supra note 18, at 57 ("I doubt that the strength of an inferior court's conviction that a particular interpretation provides the best reading will—or should-influence the Supreme Court's independent judgment."); Henry J. Friendly, The "Law of the Circuit" and All That, 46 St. John's L. Rev. 405, 407 (1972) ("I doubt whether many of the Justices even read our opinions, at least on constitutional issues, except as these are filtered through the briefs of counsel or the memoranda of law clerks.").

291 See supra Section II.B. The case for waiting is especially weak when a state court and federal circuit court have decided a constitutional question, applicable to the single state alone, and are at loggerheads. In such an instance, no other avenue for redress-such as a conflict arising between another state court and its federal circuit-will be at play, and the conflict and the problems it generates will simply fester.

292 Burnet v. Coronado Oil \& Gas Co., 285 U.S. 393, 406 (1932) (Brandeis, J., dissenting); see Letter from Oliver Wendell Holmes to Franklin Ford (Feb. 8, 1908), in The Essential Holmes 201 (Richard A. Posner ed., 1992) ("[O]ne of the first things for a court to remember is that people care more to know that the rules of the game will be stuck to, than to have the best possible rules."); see also Sanford Levinson, Assessing the Supreme Court's Current Caseload: A Question of Law or Politics?, 119 Yale L.J. Online 99, 100 (2010) (stating that it need not be the case that "the Court's own decision will exhibit any particularly great wisdom or serve the country well. Rather, it is an almost Hobbesian argument that there must be a sovereign to resolve controversies, and that such a role should be played . . by the Supreme Court.").

293 See Michael W. McConnell, The Rule of Law and the Role of the Solicitor General, 21 Loy. L.A. L. Rev. 1105 (1988); David R. Strauss, The Solicitor General and the Interests of the United States, 61 Law \& Contemp. Probs. 165 (1998).

294 Involvement of the Solicitor General in the certification process is not without precedent. See, e.g., United States v. Md. Casualty, 278 U.S. 663 (1928) (where Solicitor General, acting on behalf of the court of appeals judges, successfully moved for the dismissal of a certificate as inadvertently made). 
to certify and have its constitutional position possibly vindicated by the nation's highest court and imposed nationwide.

Finally, it might be asserted that the proposal advanced here will flood the Court with an unmanageable influx of cases. Such a concern has little warrant, however, given the limited expansion outlined here. The conflicts identified in Part II, despite the considerable difficulties they create, number roughly only twenty; a volume that could be easily absorbed in a single Term $^{295}$ given the Court's modest-sized docket. ${ }^{296}$ Nonetheless, to the extent the Court feels that its increased workload is too onerous, it could grant certiorari in fewer cases involving federal statutory interpretation conflicts, which as commentators have noted present less pressing need for uniformity. ${ }^{297}$

\section{ConClusion}

Although it has long been accepted that state and lower federal courts enjoy concurrent authority over the interpretation and application of the U.S. Constitution, ${ }^{298}$ little attention has been paid to the ramifications of this power-sharing arrangement. ${ }^{299}$ This Article has sought to remedy the deficit by shining a spotlight on a particularly important outgrowth of state-federal concurrent authority: the conflicting positions on federal constitutional criminal procedure doctrine adopted by federal circuit and state courts within individual states. ${ }^{300}$

295 Inasmuch as the conflicts identified here are not intended to be exhaustive in number, and more exist or come into existence, they could be addressed over two or more Terms.

296 While today the Court decides roughly 80 cases a year, as recently as 1985 it decided 161 cases and in 1930 it decided 235 cases annually. Starr, supra note 36, at 1369. With respect to the Fourth Amendment alone, as late as its 1990 Term, the Court resolved ten cases a year. See Davies, supra note 210, at 1041 tbl.1.

297 See Martha Dragich, Uniformity, Inferiority, and the Law of the Circuit Doctrine, 56 Loy. L. REv. 535, 549 n.77 (2010) (condemning the undue emphasis on certiorari grants in cases involving federal statutory conflicts, made in the name of achieving uniformity, while acknowledging that "[o]f course, individual rights ought to be protected uniformly across the country"); Amanda Frost, Overvaluing Uniformity, 94 VA. L. Rev. 1567, 1569 n.5 (2008) (noting the same and that "[v]aried interpretation of federal constitutional law raises different, and arguably more troubling, questions").

298 See supra notes 13-14 and accompanying text.

299 See Devins \& Mansker, supra note 77, at 457 (footnote omitted) ("Notwithstanding the profound and ever-growing influence of state supreme courts, their decision making receives scant attention from journalists and legal academics.").

300 The deficit is all the more glaring given the recent scholarly examination of state court interpretation of federal statutory law. See, e.g., Anthony J. Bellia, Jr., State Courts and the Making of Federal Common Law, 153 U. PA. L. Rev. 825, 851 (2005); Abbe R. Gluck, Intersystemic Statutory Interpretation: Methodology as "Law" and the Erie Doctrine, 120 YALE L.J. 1898, 1904 (2011). 
As this Article makes clear, creation of a "crazy quilt" of conflicting federal constitutional rights, which Justice Scalia has inveighed against, ${ }^{301}$ generates an array of distinct and quite significant difficulties when localized. Yet the problems and the conflicts giving rise to them often go unaddressed by the Supreme Court, whose discretionary certiorari-based docket remains smaller than at any time in its modern history.

In response, this Article has proposed that Congress amend the federal certification statute to allow state and federal circuit courts to certify questions in instances of intrastate federal constitutional conflict. ${ }^{302}$ Doing so not only will compel the Court to fulfill its role as the nation's ultimate arbiter of constitutional disputes and cure the serious problems that they create; it will also elevate state courts to their rightful place in federal constitutional discourse and afford a mechanism for greater engagement between state and lower federal courts and the nation's "one supreme Court," charged with overseeing their work and ensuring federal constitutional consistency.

301 Kansas v. Marsh, 548 U.S. 163, 185 (2006) (Scalia, J., concurring); see also Fred P. Graham, The Self-Inflicted Wound 40 (1970) (suggesting that the "checkerboard of [criminal procedure] rights" during the pre-incorporation period "had to be short-lived"). 302 While the discussion here focuses on constitutional criminal procedure, which as discussed presents particularly important questions of government power affecting liberty and privacy, the certification mechanism proposed could extend to other contested federal constitutional questions, which create similar difficulties. However, any expansion would of course have corresponding direct impact on the Court's docket, which must be weighed. 


\section{APPENDIX}

\section{Adopting the position that federal circuit precedent is not binding (46 states and the District of Columbia):}

State v. Crossman, 687 So. 2d 817, 820 (Ala. 1996); Harrison v. State, 791 P.2d 359, 363 (Alaska 1990); State v. Swoopes, 166 P.3d 945, 956 (Ariz. 2007); Sheridan v. State, 247 S.W.3d 481, 484 (Ark. 2007); People v. Camacho, 3 P.3d 878, 882 n.1 (Cal. 2000); People v. Barber, 799 P.2d 936, 941 (Colo. 1990); State v. Smith, 881 A.2d 160, 181 (Conn. 2005); Holloway v. United States, 951 A.2d 59, 63 (D.C. 2008); State v. Dwyer, 332 So. 2d 333, 335 (Fla. 1970); Perez v. State, 657 S.E.2d 846, 848 (Ga. 2008); Loher v. State, 193 P.3d 438, 452 n.16 (Haw. 2008); State v. Harmon, 685 P.2d 814, 817 (Idaho 1984); People v. Brisbon, 544 N.E.2d 297, 308 (Ill. 1989); Jackson v. State, 830 N.E.2d 920, 921 (Ind. 2005); State v. Louwrens, 792 N.W.2d 649, 652 (Iowa 2010); ${ }^{303}$ State v. Anderson, 136 P.3d 406, 415 (Kan. 2006); Cook v. Popplewell, 394 S.W.3d 323, 346 (Ky. 2011); State v. Strickland, 683 So. 2d 218, 230 (La. 1996); State v. Gardner, 509 A.2d 1160, 1163 (Me. 1986); Coard v. State, 403 A.2d 826, 829 (Md. 1979); Comm. v. Murphy, 862 N.E.2d 30, 39 (Mass. 2007); People v. Gillam, 734 N.W.2d 585, 590 (Mich. 2007); State v. Roeschelein, 776 N.W.2d 480, 485 n.1 (Minn. 2009); Fulgham v. State, 47 So. 3d 698, 701 (Miss. 2010); State v. Storey, 901 S.W.2d 886, 900 (Mo. 1995); State v. Robinson, 82 P.3d 27, 30 (Mont. 2003); In re 3628 V Street, 628 N.W.2d 272, 277 (Neb. 2001); State v. Addison, 8 A.3d 118, 126 (N.H. 2010); Blanton v. N. Las Vegas Mun. Court, 748 P.2d 494, 500 (Nev. 1987); State v. Coleman, 214 A.2d 393, 404 (N.J. 1965); State v. Fiorina, 495 P.2d 1379, 1388 (N.M. 1972); People v. Kan, 574 N.E.2d 1042, 1045 (N.Y. 1991); State v. McDowell, 310 S.E.2d 301, 310 (N.C. 1984); In re R.W.S., 728 N.W.2d 326, 329 (N.D. 2007); State v. Burnett, 755 N.E.2d 857, 862 (Ohio 2001); Phillips v. Williams, 608 P.2d 1131, 1135 (Okla. 1980); State v. Rinkin, 917 P.2d 1035, 1041 (Or. 1996); Hall v. Penn. Bd. Prob. \& Parole, 851 A.2d 859, 865 (Pa.

303 While the Louwrens court made clear its willingness to disagree with the Eighth Circuit, McNabb v. Osmundson, 315 N.W.2d 9 (Iowa 1982), leaves some doubt. See id. at 13 (" $[\mathrm{T}]$ he federal judiciary is supreme in exposition of the law of the United States Constitution .... We therefore make no attempt to arrive at our own independent interpretation of the United States Constitution, but follow the federal decisions as we understand them."). McNabb, however, cited only U.S. Supreme Court precedent in support. In addition, the Iowa Supreme Court is earlier on record as unequivocally insisting on its autonomy, at least vis-à-vis interpreting federal statutory law. See Iowa Nat'l Bank v. Stewart, 232 N.W. 445, 454 (Iowa 1930) ("Until the Supreme Court of the United States has spoken, state courts are not precluded from exercising their own judgment upon questions of federal law. They are not concluded by, though they should give respectful consideration to, the decisions of the federal Circuit Courts of Appeals . . .." (citing Wells v. W. Union Telegraph Co., 123 N.W. 371 (Iowa 1909))), rev'd on other grounds, 284 U.S. 239 (1931). Wells, despite its age, appears to remain good law in Iowa. See, e.g., Top of Iowa Coop. v. Sime Farms, 608 N.W.2d 454, 460 (Iowa 2000) (citing Wells for the proposition that the Iowa Supreme Court need only "give respectful consideration" to the lower federal court decisions concerning federal statutory law). 
2004); State v. Ware, 418 A.2d 1, 4 (R.I. 1980); In re Delgado, 306 S.E.2d 591, 596 (S.C. 1983); State v. Wright, 791 N.W.2d 791, 799 (S.D. 2010); Strouth v. State, 999 SW.2d 759, 765 (Tenn. 1999); Ex parte Dangelo, 339 S.W.3d 143, 151 (Tex. 2010); State v. Austin, 685 A.2d 1076 (Vt. 1996); In re Markel, 111 P.3d 249, 253 n.4 (Wash. 2005); Cook v. Lilly, 208 S.E.2d 784, 786 (W. Va. 1974); State v. Mechtel, 499 N.W.2d 662, 666 (Wis. 1993).

\section{Adopting a deferential position (1 state):}

Atlas Mut. Ben. Ass'n v. Portscheller, 46 A.2d 643, 646 (Del. 1945).

\section{Position uncertain (3 states):}

Utah, Virginia, ${ }^{304}$ Wyoming. 
